\title{
The neotropical genus Glyptoma ERICHSON, 1839 with descriptions of new species and a key to the species (Coleoptera: Staphylinidae: Osoriinae)
}

\author{
With 23 figures and 3 maps
}

ULRICH IRMLER ${ }^{1}$

${ }^{1}$ Institute for Ecosystem Research, Dept. Applied Ecology, University of Kiel, Olshausenstrasse 40, 24098 Kiel, Germany. - uirmler@ ecology.uni-kiel.de

Published on 2015-12-21

\section{Summary}

The Neotropical genus Glyptoma was revised with 18 species currently known from Central and South America. The following new species are described: G. rossii, G. simile, G. lescheni, G. guinanense, G. amazonense, G. schuhi. The following new synonyms are established: G. cicatricosa Motschulsky, 1857 = G. longipes SHARP, 1887; G. opacum (SHARP, 1876) = G. zischkai (SCHEerpeltz, 1970); G. crassicorne ERICHSON, 1840 = G. cribellum SHARP, 1887; G. denieri (BERNHAUER, 1939) = G. sanctaecatharinae (SChEerpeltZ, 1970); G. nitens (BERnhAUER, 1908) = G. reichenspergi (SCHEeRPELtZ, 1970); G. nitidum (Bernhauer, 1908) = G. bolivianus (SCHEERPELtz, 1970) and G. trinidadense BlaCKWELDER, 1943. Glyptoma simplex (WENDELER, 1955) is transferred to the genus Espeson with the following new synonym established: Espeson simplex (WENDELER, 1955) = Espeson simplex IRMLER, 2012.

\section{Key words}

Neotropics, new species, key to species, Coleoptera: Staphylinidae: Osoriinae

\section{Zusammenfassung}

Die neotropische Gattung Glyptoma wurde revidiert. Sie umfaßt zur Zeit 18 Arten aus Zentral- und Südamerika. Die folgenden Arten wurden neu beschrieben: G. rossii, G. simile, G. lescheni, G. guinanense, G. amazonense, G. schuhi. Folgende neue Synonyme ergaben sich: G. cicatricosa Motschulsky, 1857 = G. longipes Sharp, 1887; G. opacum $($ ShARp, 1876) = G. zischkai (Scheerpeltz, 1970); G. crassicorne Erichson, 1840 = G. cribellum Sharp, 1887; G. denieri $($ Bernhauer, 1939) = G. sanctaecatharinae (SCHEERPELTZ, 1970); G. nitens (BERnhAuer, 1908) = G. reichenspergi (Scheerpeltz, 1970); G. nitidum (Bernhauer, 1908) = G. bolivianus (Scheerpeltz, 1970) und G. trinidadense Blackwelder, 1943. Glyptoma simplex (Wendeler, 1955) gehört in die Gattung Espeson mit dem folgenden neuen Synonym: Espeson simplex (WENDELER, 1955) = Espeson simplex IrMLER, 2012.

\section{Key words}

Neotropis, neue Arten, Artenschlüssel, Coleoptera: Staphylinidae: Osoriinae 


\section{Introduction}

The genus Glyptoma is distributed in the Neotropical region only. It was first described by ERICHSON (1840) including six species from America and Europe. According to SCHENKLING (1894) the name Glyptoma is derived from the Greek word 'sculptured' and refers to the deeply sculptured surface of many species. ERICHSON used the genus name as neuter plural which can be seen by the neuter ending of crassicorne. He certainly derived the name from the several deeply sculptured carinae on pronotum and elytra. Later Motschulsky (1857) described G. cicatricosa which might be either neuter plural or feminine. Sharp (1987) in his descriptions of Central American species also used Glyptoma as neuter. In contrast, Herman (2001) used Glyptoma as feminine and changed all described species to feminine endings. Here, the original intention of Erichson is maintained using the neuter plural endings.

ERICHSON (1840) included the species of MotsCHULSKY's (1837) Thoracophorus into Glyptoma with G. crassicorne as genotype fixed by DuponCHEL 1841 (BLACKWELDER 1952). Later, Fauvel (1891) used the name Calocerus for Glyptoma. But Calocerus FAUvel, 1891 was preoccupied by Calocerus LeConte 1853 (see BLACKWELder 1952 and Herman 2001). The species of the two genera Glyptoma and Thoracophorus are clearly separated by the structure of the antennae that are clubbed in Thoracophorus, but not in Glyptoma and by the procoxae that are separated by a process in Glyptoma and contiguous in Thoracophorus. According to IrMLER (2010) within the subtribe Thoracophorina Glyptoma is most related to the genera of the Dirocephalus-group, whereas Thoracophorus forms a group with the genera Rhopalopherus BERnHAUER, 1909 and Mesotrochus WASMANN, 1890.

The genus Glyptoma is restricted to the Neotropical region, whereas Thoracophorus is world-wide distributed. In the Neotropics, the genus Glyptoma is known from the tropical regions of Central and South America from Guatemala to northern Argentina. Southern Brazil seems to be a hot spot of species richness with 8 species. SCHEERPELTz (1970) provided a key to the known Glyptoma (Calocerus) species and described several new species. Unfortunately, he did not study the aedeagi and made many mistakes in measuring the size of species. Therefore, all species described by ScheERPeltz (1970) were synonymised. Furthermore, species described by SHARP (1887) that were based on single female type specimens were synonymised. Their status might change if more material is available. The present study will provide the descriptions of new species and a key to the species. Furthermore, the geographical distribution is discussed.
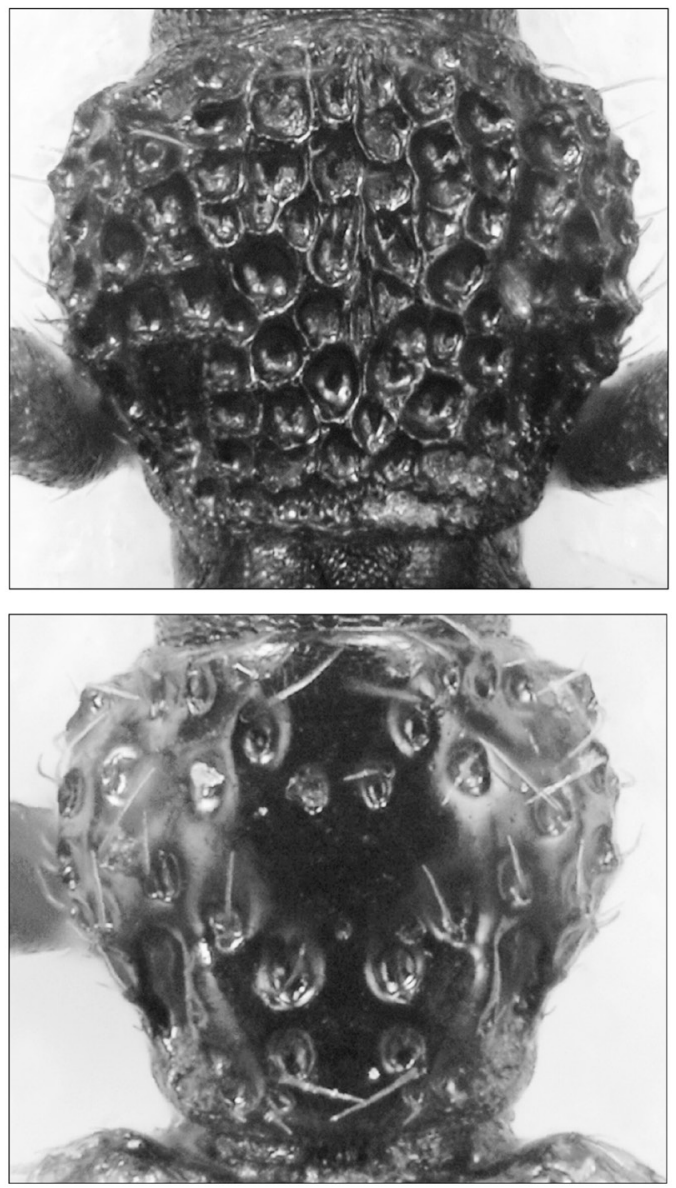

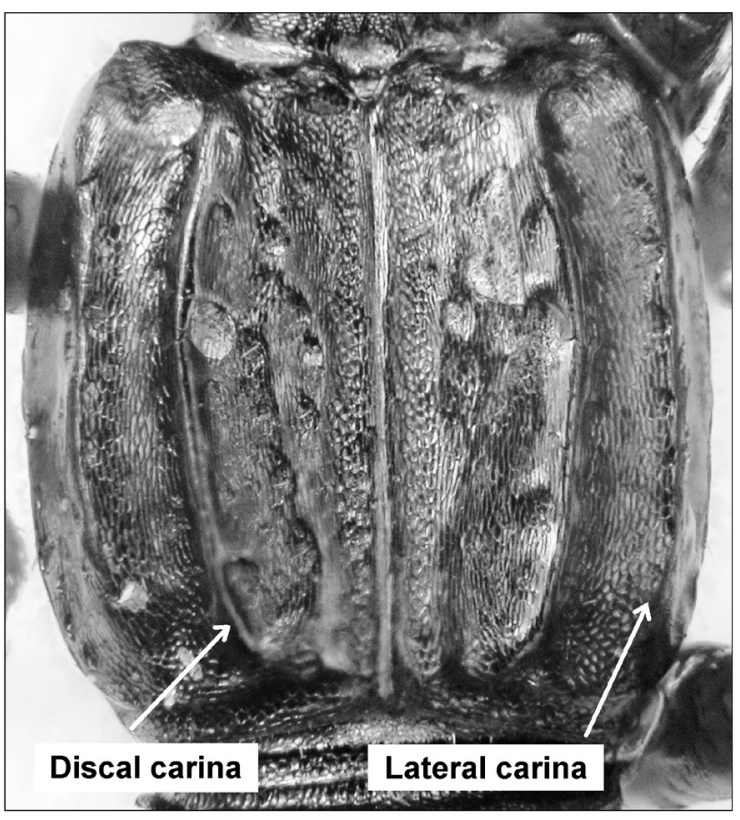

Fig. 1: Pictures of pronotal punctation (left) with pseudo-punctures (upper) and normal setiferous punctures (lower) and elytral carinae (right). 


\section{Material and methods}

The material of the following museums and private collections has been studied:

AMNH American Museum of Natural History, New York, USA

KNHM Kansas Natural History Museum, Snow Entomological Collections, Lawrence, Kansas, USA

NHMW Natural History Museum, Wien, Austria

SDEI Senckenberg Deutsches Entomologisches Institut, Müncheberg, Germany

ZMHU Zoological Museum of Humboldt University, Berlin, Germany

ZMML Zoological Museum of the Moscow Lomonosov State University, Moscow, Russia

MSC Michael Schülke Collection, Berlin, Germany

UIC Ulrich Irmler Collection, Ploen, Germany

VAC Volker Assing Collection, Hannover, Germany

For the measurements of the total length, the intersegmental space of abdominal segments was considered. The lengths of individual tagmata were determined along the midline, their width at the widest part of the respective tagma. The length/width ratio is abbreviated as L/W.

Pronotal punctures are characterized as normal punctures and pseudo-punctures. The normal punctures are defined as small punctures with more or less central seta. Pseudo-punctures are defined as large deep impressions without central seta. Setae are located on ridges between the pseudo-punctures or eccentric to centre of pseudopunctures (Fig. 1). On the elytra two carinae can exist, an inner one on disc and a lateral one near margin. The inner one is named discal carina, the lateral one, lateral carina (Fig. 1). The lateral carina is lost in some species or extremely indistinct.

For the photographs, a Makroskop M 420 (Wild Herbrugg) was used in combination with a digital camera (Leica EC3) and CombineZ5 (HADLEY 2006) for optimising the depth of focus.

\section{Acknowledgement}

I thank the following curators of the museums for their kind support and loaning their Glyptoma material: L. Herman (AMNH), J. S. Ashe and Z. Falin (KNHM), J. Frisch (ZMHU), S. Blank (SDEI), H. Schillhammer (NHMW), A. Gusakov (ZMML). I further thank Volker Assing and Jiri Janak for providing me their material for the study and some specimens for my collection.

\section{Description of species}

\section{Group of Glyptoma cicatricosa}

This species group is characterised by the large size of $3.5 \mathrm{~mm}$ to $4.0 \mathrm{~mm}$ and relatively long antennae with middle antennomeres as long as wide as or longer than wide.

\section{Glyptoma cicatricosa MoTSCHULSKY, 1857}

(Figs 4A, B, 20 B)

Glyptoma cicatricosa Motschulsky, 1857: 494

Glyptoma longipes SHARP, 1887: 723 new synonymy

Type material examined: 2 males, Columbia: Colomb. Without further data (ZMML). Both specimens in ZMML had identical labels. One male is herein designated as lectotype by fixing a lectotype label to the pin. G. longipes SHARP, 1887:female, holotype: Guatemala: Cerro Zunil, leg. Champion (BMNH).

Further material examined: Guatemala: female, without further data, leg. Conradt (SDEI); Costa Rica: 5 females, Puntarenas Prov., Las Cruces, Biol. Sta. $\left(82^{\circ} 57.58^{\prime} \mathrm{W}, 8^{\circ} 47.14^{\prime} \mathrm{N}\right), 1330 \mathrm{~m}$ elev., under bark, 29.5.2004, leg. J. S. Ashe, Z. Falin, I. Hinojosa (KNHM, UIC), \#CR1AFH04024; Columbia: male, without further data, leg. Wehnke, coll. Kraatz (SDEI); without further data, leg. Thovey, coll. Kraatz (SDEI); Venezuela: male, without further data, col. Dr. Moritz (NHMW); St. Cristobal $\left(72^{\circ} 11^{\prime} \mathrm{W}, 7.44^{\prime} \mathrm{N}\right)$, West-Venezuela, coll. Klima (NHMW); male, Carabobo, Mun. Bejuma, Via Palmichal $\left(61^{\circ} 24^{\prime} \mathrm{W}, 6^{\circ} 18^{\prime} \mathrm{N}\right), 750-850 \mathrm{~m}$ elev. 11.2005, leg. Brachat (UIC); male, Yaracuy, San Felipe env., Sierra de Aroa (68 $\left.50^{\prime} \mathrm{W}, 10^{\circ} 22^{\prime} \mathrm{N}\right), 1300-1600 \mathrm{~m}$ elev., 19.11.2005, leg. Brachat (VAC); female, Aragua, $16 \mathrm{~km} \mathrm{~N}$. Maracay $\left(67^{\circ} 29^{\prime} \mathrm{W}, 10^{\circ} 24^{\prime} \mathrm{N}\right), 1500 \mathrm{~m}$ elev., under bark, 7.3.1995, leg. R. Brooks, \#53 (KNHM); Guyana: female, Region 8, Iwokrama Forest, Turtle Mt., base camp $\left(58^{\circ} 43.5^{\prime} \mathrm{W}\right.$, $\left.4^{\circ} 43.5^{\prime} \mathrm{N}\right), 50 \mathrm{~m}$ elev., under bark, 1.6.2001 leg. R. Brooks, Z. Falin, \#GUY1BF01 (KNHM); French Guyana: 3 females, Réserve Trésor ( $\left.52^{\circ} 16.44^{\prime} \mathrm{W}, 4^{\circ} 36.37^{\prime} \mathrm{N}\right), 225 \mathrm{~m}$ elev., collected by Window trap, 9.2009, 12.2009, leg. S. Brulé (BMNH); 4 females, Saül, under bark, MarchApril 1999, leg. A. Berkov (AMNH).

Diagnosis: Unfortunately, the type specimen of G. longipes is a female and the specimens of Costa Rica are also all females. I found no distinct differences between the Central American specimens and the northern South-American specimens. Moreover, SHARP (1887) did not compare G. longipes with G. cicatricosa. Therefore, I synonymised $G$. longipes with $G$. cicatricosa. The differences between the two species given by SCHEERPELTz (1970) are not correct. Type specimens of both G. longipes and G. cicatricosa are 4.0 and $4.2 \mathrm{~mm}$ long, 
respectively, and not 4.2 and $4.5-5.0 \mathrm{~mm}$ as published by SCheerpeltz (1970). The species is very similar to $G$. rossii and G. laeviceps. It can be differentiated from G. laeviceps by the diagonal micro-striae of the head and from both species by the absence of the lateral carinae on the elytra: The aedeagus strongly resembles that of G. rossii, but the parameres are shorter and the central lobe is less angulate. Unfortunately, beside the two type specimens only three male specimens were found in the material studied. They all showed no differences in the aedeagus.

Description: Length: 3.5-3.9 mm. Colouration: Black; antennae dark brown, legs slightly lighter brown.

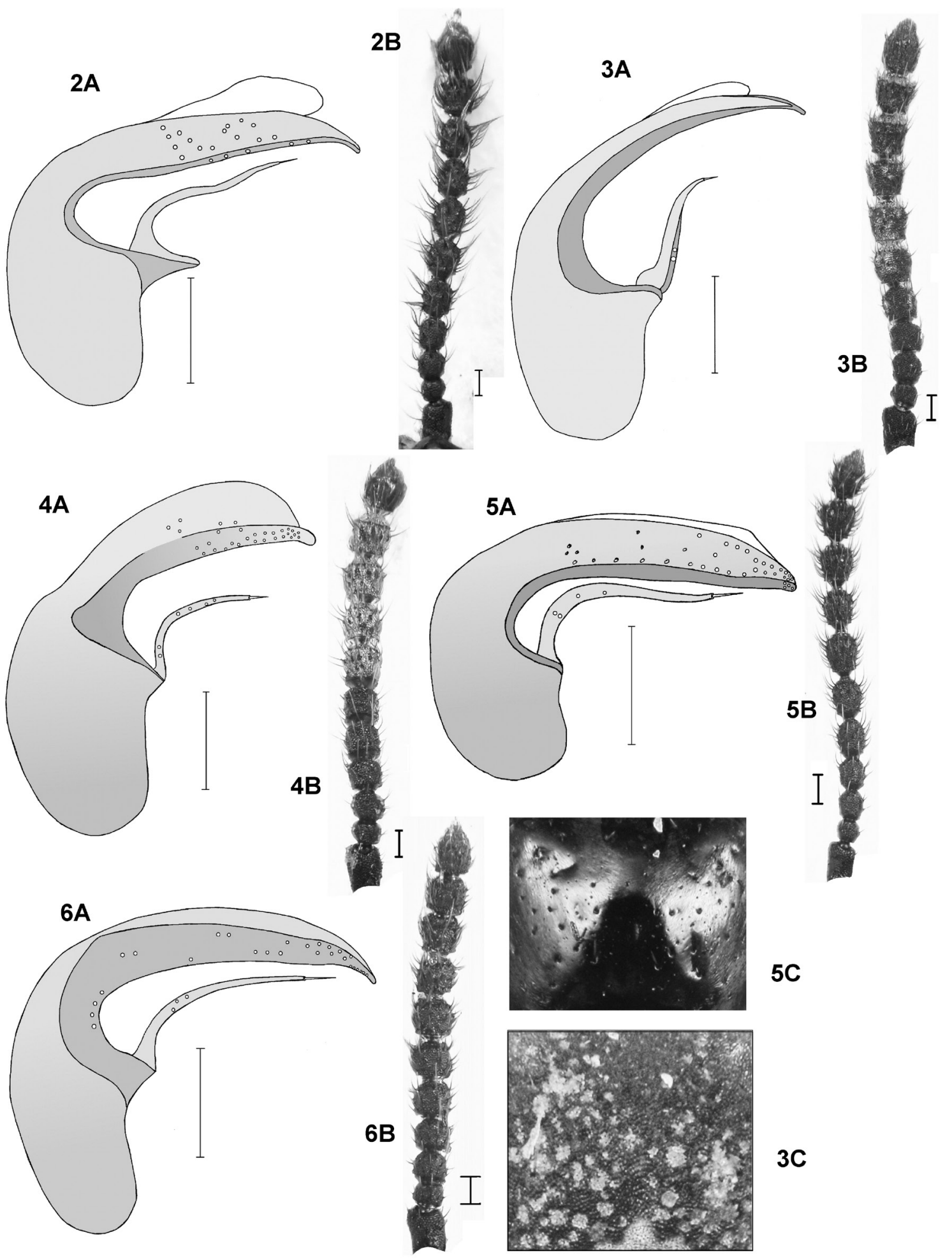

Figs 2-6: Aedeagus (A), antenna (B) and microsculpture of head (C) of Glyptoma laeviceps (2), G. opacum (3), G. cicatricosa (4), G. rossii (5), G. simile (6); scale bar: $0.1 \mathrm{~mm}$. 
Head: $0.51 \mathrm{~mm}$ long, $0.63 \mathrm{~mm}$ wide; eyes large, slightly prominent; longer than temples; temples convergent; narrowed to neck in smooth convex curve; sides in front of eyes parallel up to base of antennae; clypeus strongly narrowed in deeply sinuate curve to front edge; punctation sparse and moderately deep; interstices between punctures two to three times as wide as diameter of punctures; on disc with several larger punctures than laterally; between large punctures with denser micro-punctation; vertex with dense diagonal micro-striae; surface of vertex matt and with iridescent shine; clypeus without microstriae; surface nearly polished.

Antennae as long as head, pronotum and half of elytra combined; first antennomere thick, approximately rectangular; 1.5 times as long as wide; second antennomere slightly narrower than first; much wider than long; third approximately quadrate; following antennomeres as wide as third, but longer than wide; tenth antennomere again approximately quadrate; antennomeres four to eleven covered by long setae; setae as long as width of antennomeres.

Pronotum: $0.60 \mathrm{~mm}$ long, $0.60 \mathrm{~mm}$ wide; widest in middle; anterior half smoothly narrowed to neck in convex curve; posterior half deeply emarginate to posterior margin; posterior angles nearly rectangular; punctation very dense; punctures very large; mostly coriaceous; interstices between punctures less than one fifth as wide as diameter of punctures; deep groove in midline of anterior half; margined by distinct ridge; in posterior half with irregular and indistinct transverse impression; surface of punctures with deep isodiametric microsculpture; ridges between punctures and along central groove without or with weak microsculpture; surface shiny.

Elytra: $0.93 \mathrm{~mm}$ long, $0.82 \mathrm{~mm}$ wide; widest in middle; sides smoothly curved in slight convex curve; shoulders shortly denticulate; shoulders and posterior angles obtuse; discal carina distinct; lateral carina absent or very shortly developed near shoulders; punctation dense and partly coriaceous; small stripe adjacent to suture impunctate; between stripe and discal carinae three irregular rows of large punctures; on lateral side of discal carinae at least three irregular rows of large punctures; interstices between punctures less than one fifth as wide as diameter of punctures; sutural impunctate stripe with dense isodiametric microsculpture; surface matt; remaining surface with less dense isodiametric or longitudinal microsculpture; surface slightly shiny; in particular, ridges between punctures more shiny than surface of punctures.

Abdomen with transverse groove at base of segments III to V; within grooves transverse line of large punctures; groove on segment III deeper than on segment V; segments VI to VIII without basal groove; outside basal groove with fine setiferous punctation; distinctness of isodiametric microsculpture decreasing from anterior to posterior segments; thus, anterior segments matt; posterior segments shiny.

Aedeagus smoothly curved from base to apex; angle between basal and apical lobe obtuse; apex shortly point- ing ventrally; numerous sensillae on sides of apical lobe; sensillae denser near apex than near base; paramere thin; with apical seta; only reaching middle of apical lobe.

\section{Glyptoma laeviceps SHARP, 1887}

(Figs 2A, B, 20A)

Glyptoma laeviceps SHARP, 1887: 723

Type material examined: Lectotype: male; Panama: Volcan de Chiriqui, 2000 - $4000 \mathrm{ft}$ elev. $\left(82^{\circ} 38^{\prime} \mathrm{W}, 8^{\circ} 46^{\prime} \mathrm{N}\right)$, under bark saturated with sap, leg. Champion (BMNH). According to SHARP (1887) two type specimens exist. I saw one male that is here designated as lectotype.

Further material: Costa Rica: Prov. Cartago, 2 males, Par. Nat. Tapanti, cloud forest litter (dry) $1650 \mathrm{~m}$ elev. $\left(83^{\circ} 46^{\prime} \mathrm{W}, 9^{\circ} 43^{\prime} \mathrm{N}\right), 18.02 .1998$, leg. R. Anderson (KNHM); 2 males, 2 females, Tuis, $2 \mathrm{~km}$ NE Rancho Naturalista $\left(83^{\circ} 33^{\prime} \mathrm{W}, 9^{\circ} 49^{\prime} \mathrm{N}\right), 2501 \mathrm{ft}$ elev., 15.-16.06.1995, leg. B. Ratcliffe, M. Jameson (KNHM, UIC); Prov. Puntarenas, 1 female, Las Alturas Stanford Biolog. Sta., ca. 29 km NE San Vito, under bark, 1500 m elev., 25.05.1993, leg. J. S. Ashe (KNHM); 1 male, 1 female, same region, $2 \mathrm{~km}$ NE Est. Biol. Alturas, upper montane/cloud forest trans. $\left(82^{\circ} 50.01^{\prime} \mathrm{W}, 8^{\circ} 56.56^{\prime} \mathrm{N}\right)$, litter, $1520 \mathrm{~m}$ elev. 10.07.1999, leg. R. Anderson (KNHM); 4 males, 2 females, Las Cruces, $11 \mathrm{~km}$ SW Estacion Biologico Las Cruces $\left(83^{\circ} 01.5^{\prime} \mathrm{W}\right.$, $8^{\circ} 46.43^{\prime} \mathrm{N}$ ), wet cloud forest litter, $1450 \mathrm{~m}$ elev., 9.07.1999, leg. R. Anderson (KNHM, UIC); 1 male, 4 females, same region $\left(82^{\circ} 57.58^{\prime} \mathrm{W}, 8^{\circ} 47.14^{\prime} \mathrm{N}\right)$, fungus covered logs, 1330 m elev., 29.05.2004, leg. J.S.Ashe, Z. Falin, I. Hinojosa (KNHM); 5 males, 2 females, Monteverde, $1570 \mathrm{~m}$ elev., collected by Berlese, 16.05.1989, leg. J. S. Ashe, R. Brooks, R. Leschen (KNHM, SDEI, UIC); 1 male, same region, Estacion Biologica $\left(84^{\circ} 47.49^{\prime} \mathrm{W}, 10^{\circ} 18.53^{\prime} \mathrm{N}\right)$, montane forest litter, $1600 \mathrm{~m}$ elev., 14.06.2001, leg. R. Anderson; 1 male, same region $\left(84^{\circ} 49.08^{\prime} \mathrm{W}, 19^{\circ} 19.4^{\prime} \mathrm{N}\right)$, montane forest litter, $1540 \mathrm{~m}$ elev., 15.05.2001, leg. R. Anderson (KNHM); 1 female, Corcovado National Park, Sirena Stn. lower Ollas Trail $\left(83^{\circ} 35.22^{\prime} \mathrm{W}, 8^{\circ} 24.48^{\prime} \mathrm{N}\right)$, under bark, $5 \mathrm{~m}$ elev., 25.06.2000, leg. Z. H. Falin (KNHM); 3 males, 1 female, San Vito, $35 \mathrm{~km} \mathrm{NE}$, nr. Las Alturas, Rio Bella Vista, Rd to Gravel Pit, dry leaf litter near river, $4300 \mathrm{ft}$ elev., 22.03.1991, 23.03.1991, leg. L. Herman (AMNH); 2 females, same region, $4 \mathrm{~km} \mathrm{~S}$ San Vito Biol Stat. Las Cruzes $\left(82^{\circ} 57.36^{\prime} \mathrm{W}, 8^{\circ} 47.3^{\prime} \mathrm{N}\right)$, leaf litter, $110 \mathrm{~m}$ elev., collected by Berlese, 19.06.1998, leg. R. Anderson (KNHM); 8 males, 12 females, same region, $5 \mathrm{~km} \mathrm{SW}$ S. Vito $\left(82^{\circ} 59.13^{\prime} \mathrm{W}, 8^{\circ} 47.13^{\prime} \mathrm{N}\right)$, leaf litter, collected by Berlese, 22.06.1998, leg. R. Anderson (KNHM, UIC); 1 female, Las Cruces, $4000 \mathrm{ft}$ elev., 01.08.1976, C. \& C. Goodnight (AMNH); 1 specimen, Tapanti $\left(83^{\circ} 47^{\prime} \mathrm{W}\right.$, $\left.9^{\circ} 42^{\prime} \mathrm{N}\right), \quad 9.09 .1939$, leg. A. Bierig (FMNH); Prov. Alajuela, 1 female, Peñas Blancas, under bark, $930 \mathrm{~m}$ elev., 20.05.1989, leg. J. S. Ashe, R. Brooks, R. Leschen (KNHM); Prov. Heredia, 2 females, 1 male, Puerto 
Viejo, Selva Biol. Stat. nr P. V. de Sarapiqui, 18.02.1985, leg. L. Herman (AMNH); Panama: 1 female, Capira, Cerro Campana $\left(79^{\circ} 57^{\prime} \mathrm{W}, 8^{\circ} 44^{\prime} \mathrm{N}\right)$, forest litter, $950 \mathrm{~m}$ elev., collected by Berlese, 5.06.1995, leg. R. Anderson (KNHM); 2 females, Darién, Cana Biol. Stat., Serrania de Pirre $\left(77^{\circ} 41.6^{\prime} \mathrm{W}, 7^{\circ} 45.18^{\prime} \mathrm{N}\right), 975 \mathrm{~m}$ elev., 4.06.1996, leg. A.R. Gillogly (KNHM); Prov. Chiriqui, 2 males, El Hato del Volcan, NW Volcán $\left(82^{\circ} 40.26^{\prime} \mathrm{W}, 8^{\circ} 49.16^{\prime} \mathrm{N}\right)$, litter near stream, $1410 \mathrm{~m}$ elev., 17.05.2001 \& 24.12.2001, leg. L. Herman (AMNH); 1 male, 1 female, same region, $27.7 \mathrm{~km}$ W Hartmann's Finca $\left(82^{\circ} 44.48^{\prime} \mathrm{W}, 8^{\circ} 52.41^{\prime} \mathrm{N}\right)$, under bark, $1580 \mathrm{~m}$ elev., 17.06.1996, leg. J. S. Ashe \& R. Brooks (KNHM); 1 male, 1 female, same region $\left(82^{\circ} 44.36^{\prime} \mathrm{W}, 8^{\circ} 51.48^{\prime} \mathrm{N}\right)$, forest litter, collected by Berlese, 1450 m elev., 14.06.1995, leg. R. Anderson (KNHM, UIC); 1 female, La Fortuna, La Reserva, 3 km W Fortuna Hwy on continental divide trail $\left(82^{\circ} 12^{\prime} \mathrm{W}, 8^{\circ} 46^{\prime} \mathrm{N}\right), 1000 \mathrm{~m}$ elev., 8.08.1995, leg. A.R. Gillogly (KNHM); 1 male, 1 female, same region, Hydro Trail $\left(82^{\circ} 14^{\prime} \mathrm{W}, 8^{\circ} 42^{\prime} \mathrm{N}\right)$, fungusy log, 1150 m elev., 9.06.1995 and 23.05.-9.06.1995 collected by flight intercept trap, leg. J. S. Ashe \& R. Brooks (KNHM); 1 female, Los Nubes, 6.7 km N Cerro Punta, P.N. Armistad $\left(82^{\circ} 34^{\prime} \mathrm{W}, 8^{\circ} 22^{\prime} \mathrm{N}\right)$, forest litter, $2150 \mathrm{~m}$ elev., collected by Berlese, 15.06.1995, leg. R. Anderson (KNHM).

Diagnosis: The species can be easily identified by the shiny head among the similarly sized species. In contrast to G. cicatricosa Motschulsky 1857 and G. rossii spec. nov., the head of G. laeviceps SHARP, 1887 is polished and without micro-striae.

Description: Length: 3.5-3.9 mm. Colouration: black, legs dark yellow, antennae dark brown.

Head: $0.45 \mathrm{~mm}$ long, $0.59 \mathrm{~mm}$ wide; eyes large and prominent; as long as temples; temples convergent to neck in convex curve; sides in front of eyes parallel; parallel part as long as eyes; then deeply sinuate to narrow clypeus; width of clypeus one third as wide as width of head; with swelling at base of antennae; punctation extremely sparse; only with few scattered small punctures; on average, interstices between punctures four to six times as wide as diameter of punctures; few punctures on vertex larger than others; without microsculpture; surface polished. Antennae nearly as long as head, pronotum and elytra combined, first antennomere thick and rectangular; second only half as long as first and distinctly smaller; third approximately quadrate; following antennomeres approximately as wide as third and longer than wide; penultimate antennomere slightly thicker and again approximately quadrate; last antennomere slightly longer than penultimate; all antennomeres with long setae; setae slightly longer than width of antennomeres; surface of antennomeres matt.

Pronotum: $0.71 \mathrm{~mm}$ long, $0.74 \mathrm{~mm}$ wide; approximately globular; slightly pear-shaped; sinuate in front of posterior angles, but angles indistinct and rounded; posterior edge not wider than mesonotum; without lateral margin; punctation irregular; punctures extremely large and cori- aceous; three punctures in anterior half on both sides of midline more deeply impressed than laterally; deep furrow along midline more deeply impressed in anterior half than in posterior half; surface of midline and of punctures with deep isodiametric microsculpture, matt; interstices between punctures with weaker microsculpture and more shiny.

Elytra: $0.98 \mathrm{~mm}$ long, $0.98 \mathrm{~mm}$ wide; sides smoothly curved; widest at middle; shoulders shortly denticulate; disc with two carinae on each side of suture; one in middle between suture and lateral margin; one from shoulders to posterior angles; on inner side of discal carina three indistinct irregular rows of large punctures; on each side of suture indistinct furrow without punctures; on outer side of discal carina and inner side of lateral carina with irregular row of smaller punctures; between these rows wider space without punctures; space between carinae inclusively surface of punctures with deep isodiametric microsculpture; in some parts microsculpture longitudinally reticulate; surface matt.

Abdomen at segments III to $\mathrm{V}$ with deep transverse groove formed by deep large punctures; posterior half of segments impunctate; surface shiny; segments VI to VIII without transverse row of large and deep punctures and surface totally shiny; only with pair of short yellow setae on both sides of midline.

Aedeagus forming nearly rectangular angle between basal and apical lobe; apical lobe long and approximately straight; acute short apex more strongly curved and pointing ventrally; inner edge of apical lobe indistinctly undulate; wider in middle than at base; with numerous sensillae in middle; thin paramere long; reaching apical third of apical lobe; in middle with undulate structure.

\section{Glyptoma opacum (SHARP, 1876) \\ (Figs 3A, B, C, 20D)}

Thoracophorus opacus SHARP, 1876: 418

Calocerus zischkai SCHEerpeltz, 1970: 132 new synonymy

Type material examined: Holotype: female, Brazil: Est. Amazonas, Tefé $\left(64^{\circ} 41^{\prime} \mathrm{W}, 3^{\circ} 21^{\prime} \mathrm{S}\right)$ (BMNH); Syntypes of Glyptoma zischkai: 1 male, 1 female, Bolivia: Region Chaparé, 400 m elev., 14.08.19954, leg. R. Zischka (NHMW).

Further material: Panama: 1 male, 3 females, Old Plantation Rd., 6.9 km S. Gamboa $\left(79^{\circ} 40^{\prime} \mathrm{W}, 9^{\circ} 05^{\prime} \mathrm{N}\right), 80 \mathrm{~m}$ elev., beating vegetation, 27.5.1995, leg. J. Jolly \& C. Chaboo (KNHM, UIC); Brazil: male, Amazonas, Téfé without further data (det. as Thoracophorus humerosus FAuvel) (BMNH); Est. Pará, 2 females, Caratatéua; Ilha de Oteiro ( $\left.48^{\circ} 25^{\prime} \mathrm{W}, 1^{\circ} 14^{\prime} \mathrm{S}\right), 15.05 .1974$, leg. R. T. Schuh (AMNH); 1 male, Jacaréacanga $\left(57^{\circ} 38^{\prime} \mathrm{W}, 6^{\circ} 16^{\prime} \mathrm{S}\right), 15.12 .1969$, leg. R. Barbosa (AMNH); female, Pará, without further data $(\mathrm{BMNH})$; French Guyana: 1 male, Roura $\left(52^{\circ} 19^{\prime} \mathrm{W}\right.$, 
$\left.4^{\circ} 43^{\prime} \mathrm{N}\right)$, 08.01.1999, leg. P. Krásensky (UIC); 2 males, without further data, leg. Charvein $(\mathrm{BMNH})$; Surinam: 1 female, Commewijne, Akintosela, $39 \mathrm{~km} \mathrm{SE}$ Suriname River bridge road to Refi Doiti $\left(54^{\circ} 55.15^{\prime} \mathrm{W}\right.$, $\left.5^{\circ} 16.17^{\prime} \mathrm{N}\right)$, under bark, $40 \mathrm{~m}$ elev., 02.07.1999, leg. Z. Falin, (KNHM); Peru: 1 male, Pucallpa, $60 \mathrm{~km} \mathrm{W.}$ Estacion IVITA $\left(74^{\circ} 80.5^{\prime} \mathrm{W}, 8^{\circ} 46.4^{\prime} \mathrm{S}\right)$, primary forest, 22.06.1988, leg. A.A. Zakharov (UIC); Bolivia: Region Chaparé ( $\left.64^{\circ} 44^{\prime} \mathrm{W}, 14^{\circ} 05^{\prime} \mathrm{S}\right), 400 \mathrm{~m}$ elev., 14.7.1954, leg. R. Zischka (NHMW).

Diagnosis: G. opacum is characterised by the large size and the totally matt surface. In contrast to G. simile, the clypeus is also covered by a dense and deep microsculpture. ScheERPELTZ (1970) distinguished G. zischkai from G. opacum by the larger size of the first species. However, in contrast to SCHEERPELTZ's measures the type specimen of G. zischkai is only $4.0 \mathrm{~mm}$ long and not 4.5 to $5.0 \mathrm{~mm}$ as published by SCHEERPELTz (1970). I found no difference between the type specimens of G. zischkai and G. opacum. The aedeagus of the G. zischkai type also shows no difference to the other male specimens identified as G. opacum (Sharp, 1876).

Description: Length: $4.0 \mathrm{~mm}$. Colouration: Black; antennae dark brown; legs slightly lighter brown.

Head: $0.48 \mathrm{~mm}$ long, $0.66 \mathrm{~mm}$ wide; eyes large; slightly prominent and as long as temples; shape of temples cheek-like; post-ocular part shortly parallel, then abruptly curved and narrowed to neck; sides of head in front of eyes parallel up to base of antennae; parallel part longer than eyes; then abruptly narrowed in sinuate curve to front margin; punctures large and dense; interstices between punctures less than one fourth as wide as diameter of punctures; surface of vertex including surface of punctures covered by dense isodiametric narrow microsculpture; surface of vertex totally matt; clypeus more sparsely punctate, but surface as matt as on vertex.

Antennae slightly shorter than head, pronotum and elytra combined; first antennomere approximately rectangular and thick; distinctly thicker and longer than short second antennomere; second antennomere one fifth narrower than first and shorter than half of length of first; following antennomeres wider; fourth antennomere as wide as first, but still wider than long; antennomeres five to ten approximately quadrate or slightly longer than wide; all antennomeres with dense setation; setae only half as long as width of antennomeres.

Pronotum: $0.61 \mathrm{~mm}$ long, $0.66 \mathrm{~mm}$ wide; approximately parallel in anterior half, in posterior half emarginate and narrowed to rounded obtuse posterior angles; sides in anterior half undulate; front margin sinuate near apical angles, thus, anterior margin slightly prominent in middle; punctation as dense and deep as on head; midline indistinctly depressed in anterior half; in posterior half with indistinct transverse impression; surface with similar dense microsculpture as head; matt.
Elytra: $0.87 \mathrm{~mm}$ long, $0.87 \mathrm{~mm}$ wide; sides slightly curved; widest in middle; shoulders smoothly curved, but shortly denticulate; inner carina distinct; lateral carina absent or indistinctly restricted shortly behind shoulders; punctures large and dense; much larger than on head and pronotum; interstices between punctures indistinct and irregular; restricted to only narrow carinae; between large punctures minute setiferous punctures; total surface including carina with same dense isodiametric microsculpture as head and pronotum; surface totally matt.

Aedeagus with narrow apical lobe; apical lobe distinctly longer than basal lobe and smoothly curved; acute apex shortly pointing ventrally; without sensillae; narrow paramere short; only half as long as apical lobe; straight with short acute apex; at base with two sensillae.

\section{Glyptoma rossii spec. nov.}

(Figs $5 \mathrm{~A}, \mathrm{~B}, \mathrm{C}, 20 \mathrm{C}$ )

Holotype: male: Ecuador: Cotopaxi, Canton Sigichos, Las Pampas, Otonga Natural Reserve $\left(78^{\circ} 53^{\prime} \mathrm{W}\right.$, $0^{\circ} 41.49 ' S$ ), 25.-28.7.2005, leg. W. Rossi (UIC). Paratypes: Ecuador: female, Pichincha, Nanegalito, $7 \mathrm{~km} \mathrm{~S}$ on Nono Road $\left(78^{\circ} 40.36^{\prime} \mathrm{W}, 0^{\circ} 00.23^{\prime} \mathrm{N}\right), 1540 \mathrm{~m}$ elev., flight intercept trap, 27.-31.10.1999, leg. Z. H. Falin (KNHM); 6 males, 2 females, Cotopaxi, Canton Sigichos, Las Pampas, Otonga Natural Reserve (78 $\left.53^{\prime} \mathrm{W}, 0^{\circ} 41.49^{\prime} \mathrm{S}\right)$, 25.-28.7.2005, leg. W. Rossi (VAC, UIC, AMNH).

Diagnosis: The species is very similar to G. cicatricosa and G. laeviceps. On average, it is slightly longer than G. laeviceps. In contrast to G. laeviceps with polished head, $G$. rossii has fine micro-striae on posterior head, which make a slight iridescent shine. However, the micro-striae are less dense than in G. cicatricosa. In the last species the iridescent shine on the posterior head is still more distinct. The species can be mainly distinguished from G. cicatricosa by the distinct lateral carina of the elytra, which is nearly absent in G. cicatricosa. In this respect, it resembles $G$. laeviceps that also carries a distinct lateral carina on the elytra. The elytral microsculpture is denser than in G. cicatricosa and G. laeviceps, in particular, on the interstices between punctures. Interstices between punctures are totally matt in G. rossii, but sligthly shiny in G. laeviceps and G. cicatricosa. The aedeagi of G. rossii and G. cicatricosa are also very similar, but can be differentiated by the shorter paramere in G. cicatricosa.

Description: Length: $3.8-4.0 \mathrm{~mm}$. Colouration: Black; antennae dark brown; legs slightly lighter brown.

Head: $0.55 \mathrm{~mm}$ long, $0.72 \mathrm{~mm}$ wide; moderately large and prominent; slightly smaller than temples; temples narrowed to neck in smooth convergent curve; posterior margin of head slightly emarginate; sides in front of eyes parallel up to base of antennae; then abruptly narrowed to front margin of clypeus in sinuate concave curve; clypeus less than half as wide as width of head; punctation sparse; 
interstices between punctures at least four to three times as wide as diameter of punctures; between normal large punctation with denser micro-punctation; few setiferous punctures on fore-head; microsculpture weak or absent; in lateral posterior parts slightly denser consisting of longitudinal or transversal micro-striae; partly shiny, partly with slight iridescent shine.

Antennae as long as head and pronotum combined; first antennomere rectangular; longer than wide; second antennomere quadrate and narrower than first; following antennomeres wider and approximately as wide as first; longer than wide; seventh antennomere 1.5 times as long as wide; tenth antennomere again approximately quadrate; antennomeres five to eleven with long setae; setae approximately as long as width of antennomeres.

Pronotum: $0.56 \mathrm{~mm}$ long, $0.66 \mathrm{~mm}$ wide; widest at middle; narrowed to anterior margin in smooth convex curve; narrowed to posterior margin in smooth concave curve; shortly in front of anterior margin with deep emargination continuing to neck-like front margin; punctation deep and dense; punctures large; interstices between punctures less than one fourth of diameter of punctures; partly punctation coriaceous without distinct interstices between punctures; in anterior half with longitudinal groove; in posterior half with transverse v-shaped groove; at posterior lateral emargination with oval groove; surface totally covered with dense and deep isodiametric microsculpture; matt.

Elytra: $0.99 \mathrm{~mm}$ long, $0.93 \mathrm{~mm}$ wide; widest at middle; sides curved in smooth convex curve from shoulders to posterior angles; shoulders obtusely rounded and without distinct denticle; discal and lateral carinae totally developed; margined by transverse ridge in front of posterior margin; between suture and discal carina with irregular large punctures; directly at inner side of discal carinae, punctures in longitudinal line and with short setae; area between discal and lateral carina without punctation except at inner side of lateral carina; longitudinal line of punctures at inner side of lateral carina; surface totally covered by dense and deep isodiametric microsculpture; matt.

Abdomen at base of segments III to $\mathrm{V}$ with transverse line of deep and large punctures forming a deep transverse groove; groove deepest on segment III and weaker on segment V; segments VI to VIII without transverse groove at base; without normal punctation; isodiametric microsculpture deep; deeper and narrower on segment III to $\mathrm{V}$ than on segment V to VIII; thus, surface of anterior segments matter than on posterior segments; segments $\mathrm{V}$ to VIII with few fine setiferous punctures.

Aedeagus with long and thick apical lobe placed in nearly rectangular angle to basal lobe; apical lobe with numerous sensillae laterally; sensillae denser near apex than at middle; base of apical lobe without sensillae; paramere long; reaching apical third of central apical lobe; with seta at apex.

Etymology: The specific name derived from the collector.
Glyptoma simile spec. nov.

(Figs 6A, B, 20E)

Type material: male Holotype: Brazil: Rio de Janeiro, leg. Squires, Sharp coll. \# 1905-313 (BMNH). Paratypes: Brazil: 2 females with same data as holotype (BMNH); 2 males, 2 females, without further data (BMNH); male, Rio de Janeiro, Sumaré, 23.11.1962, leg. H. Schubart (UIC); male, same location, 29.5.1960, leg. H. Schubart \& J. Becker (UIC); 4 females, Rio de Janeiro, Floresta de Tijuca, 17.7. \& 27.7.1960, leg. H. Schubart (UIC); Suriname: female, Marowijne, Nassau Mountain (54²36.20'W, $4^{\circ} 48.56$ 'N), 480 m elev., under bark, 3.6.1999, leg. Z. Falin, \#SUR1F99017 (KNHM); French Guiana: female, Roura, $8.4 \mathrm{~km} \mathrm{SSE}\left(52^{\circ} 13.25^{\prime} \mathrm{W}, 4^{\circ} 4041^{\prime} \mathrm{N}\right), 200 \mathrm{~m}$ elev., under bark, 23.5.1997, leg. J. Ashe \& R. Brooks, \#FG1AB97008 (KNHM); Guyana: female, Region B, Iwokrama Forest, Pakatau hills $\left(59^{\circ} 01.36^{\prime} \mathrm{W}, 4^{\circ} 44.54^{\prime} \mathrm{N}\right), 70 \mathrm{~m}$ elev., under bark, 28.5.2001, leg. R. Brooks \& Z. Falin, \#GUY1BF01052 (KNHM); female, same region, 26 km SW Kurupukari, Iwokrama Mt., base camp, $\left(58^{\circ} 48.38^{\prime} \mathrm{W}, 4^{\circ} 20.17^{\prime} \mathrm{N}\right), 60 \mathrm{~m}$ elev., under bark, 24.5.2001, leg. R. Brooks \& Z. Falin, \#GUY1BF01019 (KNHM); female, same region, Kabocalli Field Stn. $\left(58^{\circ} 30.35^{\prime} \mathrm{W}, 4^{\circ} 17.4^{\prime} \mathrm{N}\right), 60 \mathrm{~m}$ elev., under bark, 4.6.2001, leg. R. Brooks \& Z. Falin, \#GUY1BF01029 (KNHM); Paraguay: 2 females, Cazzaapa, Hermosa, prop. Lopez family, San Rafael Reserve $\left(55^{\circ} 44.29^{\prime} \mathrm{W}\right.$, $26^{\circ} 18.56$ 'S), 80 m elev., under bark, 1.12.2000, leg. Z. Falin \#PAR1F00081 (KNHM).

Diagnosis: The species resembles G. opacum (Sharp, 1876) in size, microsculpture and matt surface. It can be easily distinguished from that species by the shinier clypeus of the head. Furthermore, the aedeagus is wider and with numerous lateral sensillae on apical lobe, whereas the aedeagus of G. opacum (SHARP, 1876) is thin and without lateral sensillae.

Description: Length: 3.6-3.8 mm. Colouration: Black; antennae dark brown; legs slightly lighter brown.

Head: $0.49 \mathrm{~mm}$ long, $0.65 \mathrm{~mm}$ wide; eyes slightly prominent; slightly longer than temples; temples narrowed to neck in smooth convex curve; post-ocular part shortly parallel; cheek-like; sides in front of eyes parallel up to base of antennae; anterior edge of clypeus sinuate; central prominent part one third as wide as total width between base of antennae; punctation dense; on vertex partly coriaceous; on clypeus and at base of antennae punctation weaker and sparser; on vertex, surface of punctures and ridges between punctures with dense and deep isodiametric microsculpture; on clypeus, microsculpture weaker; in particular, ridges between punctures shiny. Antennae as long as head, pronotum and half of elytra combined; first antennomere nearly rectangular, slightly longer than wide; second antennomere narrowed and shorter; wider than long; following antennomeres slightly wider than second; approximately quadrate and with long setae; setae nearly as long as width of antennomeres. 
Pronotum: $0.61 \mathrm{~mm}$ long, $0.66 \mathrm{~mm}$ wide; widest in anterior half; anterior half slightly curved in convex curve, but nearly parallel; posterior half deeply emarginate; at obtuse posterior angles as wide as mesonotum; anterior angles widely rounded; densely and deeply punctate; large punctures in irregular longitudinal rows; on average, interstices less than one third as wide as diameter of punctures; mostly restricted to small ridges between punctures; isodiametric microsculpture deep and dense; totally covering surface including surface of punctures; at posterior angles punctures combined to indistinct impression; surface matt.

Elytra: $0.87 \mathrm{~mm}$ long, $0.84 \mathrm{~mm}$ wide; widest at middle; shoulders widely rounded; shortly denticulate; sides smoothly curved to obtuse posterior angles; discal carinae distinct; lateral carinae irregular and indistinct; partly absent; punctation deep and dense; large punctures partly coriaceous; interstices restricted to small ridges; surface totally covered by deep isodiametric microsculpture; surface matt.

Abdomen on segments III to VI with large punctation similar to that of elytra; segments VII and VIII with finer punctation; on each segment several punctures with long setae; remaining punctures with short setae; segments III to VI with dense and deep isodiametric microsculpture; surface matt; segments VII and VIII with weak microsculpture; surface moderately shiny.

Aedeagus with basal lobe and apical lobe forming nearly rectangular angle; apical lobe at inner side slightly sinuate near apex; acute apex pointing ventrally; laterally with numerous sensillae; sensillae denser at apex than close to basal lobe; paramere elongate; reaching apical third of apical lobe; at apex of paramere with one long seta; few sensillae near base of paramere.

Etymology: The species name derived from the same Latin word meaning similar and refers to the similarity to G. opacum (SHARP, 1876).

\section{Group of Glyptoma crassicorne}

This species group contains species of $2.5 \mathrm{~mm}$ to $2.9 \mathrm{~mm}$ length. Antennomeres are wider than long. The pronotum and elytra are densely covered by pseudo-punctures which are at least on the elytra covered by a dense isodiametric microsculpture with matt surface.

\section{Glyptoma amazonense spec. nov.}

(Figs 10A, B, 21D)

Type material: male, Holotype: Brazil, Amazonas, Manaus, $26 \mathrm{~km}$ NE of Manaus, Reserva Ducke, collected by flight intercept trap, 1995-1996, \#BMNH\{E\} 2003-84 (BMNH); Paratypes: 2 females with same data as holotype (BMNH); same location, $25 \mathrm{~km}$ NNE Manaus, under bark in secondary forest, $120 \mathrm{~m}$ elev., female, 26.7.1973, leg. R. T. Schuh (AMNH).

Diagnosis: The species mostly resembles G. guianense spec. nov. The differentiating characters between the two species are listed there.

Description: Length: 2.5-2.6 mm. Colouration: Black; legs and antennae dark brown; tarsi lighter yellow brown. Head: $0.35 \mathrm{~mm}$ long, $0.49 \mathrm{~mm}$ wide; eyes prominent; nearly twice as long as temples; temples behind eyes slightly narrowed; nearly parallel; then, shortly narrowed to neck; cheek-like; posterior edge triangularly emarginate; adjacent to eyes with short groove; sides in front of eyes parallel up to base of antennae; parallel part approximately 1.5 times as long as eyes; then abruptly narrowed in sinuate curve to anterior edge of clypeus; anterior edge of clypeus one third as wide as distance between base of antennae; pseudo-punctures large and slightly elongate; in irregular transverse lines; first line between base of antennae consisting of 6 punctures; interstices between pseudo-punctures restricted to narrow ridges; few setiferous punctures on clypeus and on ridges between pseudo-punctures; longitudinal groove behind eyes dividing vertex from temples; groove deeper at neck than close to eyes; isodiametric microsculpture deep and wide; surface matt.

Antennae slightly longer than head and pronotum combined; width of antennomeres slightly increasing from second antennomere to apical antennomeres; second antennomere slightly narrower that first and nearly twice as wide as long; third antennomere nearly quadrate; following antennomeres slightly wider than long; second to tenth antennomeres with few long yellow setae; setae as long as width of antennomeres.

Pronotum: $0.40 \mathrm{~mm}$ long, $0.46 \mathrm{~mm}$ wide; widest near middle; narrowed to anterior angles in smooth convex curve; anterior angles widely rounded; narrowed posterior angles in distinct concave curve; posterior angles obtusely rounded; with extremely deep pseudo-punctures; thus, in dorsal aspect lateral edge denticulate; on disc, pseudo-punctures deeper and larger than laterally; close pair of large pseudo-punctures near middle; behind this pair another pair of still larger punctures separated by bulge in width of anterior pair; mostly, interstices between pseudo-punctures restricted to narrow ridges; few setiferous punctures on ridges; at posterior angles with deep impression; coarse microsculpture isodiametric; on disc, partly finer and longitudinal; surface matt. Elytra: $0.60 \mathrm{~mm}$ long, $0.59 \mathrm{~mm}$ wide; widest in middle; sides slightly curved from shoulders to obtuse posterior angles, but nearly parallel; shoulders distinct; obtusely rounded; anterior edge slightly concave; discal and lateral carinae indistinct; lateral carina nearly absent; suture line deep; continuing at posterior edge to posterior angles; between suture line and discal carina two irregular rows of pseudo-punctures; between discal carina and lateral carina three irregular rows of pseudo-punctures; 
pseudo-punctures extremely large; interstices between pseudo-punctures irregularly wide; partly restricted to narrow ridges; partly half as wide as diameter of pseudopunctures; few setiferous punctures on ridges between pseudo-punctures; irregular microsculpture distinct; mostly meshes isodiametric, partly longitudinal; within suture line, microsculpture denser; total surface matt. Abdomen with one transverse row of large pseudopunctures; setiferous punctures on ridges between pseudo-punctures; microsculpture distinct; surface matt. Aedeagus with nearly rectangular angle between basal lobe and apical lobe; apical lobe sinuate in front of acute apex; several sensillae laterally; paramere short and thin with short apical seta.

Etymology: The species name derived from the Brazilian state Amazonas, where the species was found.

\section{Glyptoma crassicorne ERICHSON, 1840 (Figs 7A, B, 21A)}

Glyptoma crassicorne ERICHSON, 1840: 908

Glyptoma cribellum SHARP, 1887: 724 new synonymy

Type material examined: Glyptoma crassicorne 3 female syntypes: Colombia: Novae Valencia, without further data (ZMHU).

Glyptoma cribellum SHARP, 1887, male syntype: Guatemala: El Tumbador, leg. G. C. Champion (BMNH); 1 male, 1 female syntypes with same data $(\mathrm{BMNH})$; male syntype, Capetilla leg. G. C. Champion (BMNH); female syntype, Zapote, leg. G. C. Champion (BMNH).

Further material examined: Mexico: 2 females, Chiapas, $4 \mathrm{~km} \mathrm{~N}$ of Escuintla, under thin bark log, sap not sticky, lowland rainforest, $120 \mathrm{~m}$ elev., leg. H. Frania, \#34 (AMNH); Belize: Cayo, Las Cuevas Research Station $\left(88^{\circ} 58.24^{\prime} \mathrm{W}, 16^{\circ} 44.00^{\prime} \mathrm{N}\right), 650 \mathrm{~m}$ elevation, 2 males collected by flight intercept trap, 22.-26.5.2000, leg. M. Caterino (BMNH); Nicaragua: 1 female, Matagalpa Dept, 6 km N Matagalpa, Selva Negra Hotel, Bavaria Trail $\left(85^{\circ} 54.53^{\prime} \mathrm{W}, 12^{\circ} 59.99^{\prime} \mathrm{N}\right), 1240 \mathrm{~m}$ elev., collected by flight intercept trap, 18.-21.5. 2002, leg. R. Brooks \& Z. Falin \#NIC1BFC02036 (KNHM); 2 females, Granada Dept., Res. Nat. Volcan Mombacho, entrance rd., 910 m elev., collected by flight intercept trap, 1.-5.6.2002, leg. R. Brooks, Z. Falin \& S. Chatzimanolis \#NIC1BFC02189 (KNHM); Costa Rica: 1 male, 1 female, Puntarenas, 7 km S Quepos, 10.2.1985, leg. L. Herman \#2104 (AMNH); 6 male, 9 females, Corcovado National Park, Sirena Stn., lower Ollas Trail $\left(83^{\circ} 24.48^{\prime} \mathrm{W}, 8^{\circ} 24.48^{\prime} \mathrm{N}\right), 5 \mathrm{~m}$ elev., on/ under bark, 25.6.2000, leg. Z. H. Falin \#CR1ABF00006A (KNHM, UIC); 2 males, same region, junc. GunacasteSirena Trails $\left(83^{\circ} 35.46^{\prime} \mathrm{W}, 8^{\circ} 28.55^{\prime} \mathrm{N}\right), 5 \mathrm{~m}$ elev., under bark, 30.6.2000, leg. Z. H. Falin \#CR1ABF00051 (KNHM); 3 males, 5 females, Golfito, 10-200 m elev., under bark, 28.5.1993, leg. J.\&A. Ashe \#067 (KNHM,
UIC); 6 males, 2 female, Las Cruces Biol. Stn. ( $82^{\circ} 5758^{\prime} \mathrm{W}$, $\left.8^{\circ} 4714^{\prime} \mathrm{N}\right), 1330 \mathrm{~m}$ elev., under bark, 30.5.2004, J. S. Ashe, Z. H. Falin \& I. Hinojosa \#CR1AFH04045 (KNHM, UIC); 9 males, 4 females, Guanacaste, Maritza, Biological Station $\left(85^{\circ} 29^{\prime} \mathrm{W}, 10^{\circ} 58^{\prime} \mathrm{N}\right)$, under bark, 4.5.1995, leg. J.S. Ashe (KNHM, UIC); male, same location, $550 \mathrm{~m}$ elev., but collected by flight intercept trap, 22.5.1993, leg. J. \& A. Ashe \#036 (KNHM); 1 female, Patilla Biological Station $\left(85^{\circ} 25^{\prime} \mathrm{W}, 10^{\circ} 58^{\prime} \mathrm{N}\right), 650 \mathrm{~m}$ elev., under bark, 2.5.1995, leg. J. S. Ashe (KNHM); same region, $550 \mathrm{~m}$ elev. bracket mushrooms, 21.5.1993, leg. J. \& A. Ashe \#033 (KNHM); Limòn, Rd. Bribri > Bratsi $\left(9^{\circ} 33.45^{\prime}-35.45^{\prime} \mathrm{N}\right.$, $\left.82^{\circ} 52.50^{\prime}-53.17^{\prime} \mathrm{W}\right) \quad 30-50 \mathrm{~m}$ elev. along river bank, secondary forest, Fincas, coll. By car net, 2.12.2013, leg. M. Schülke \& B. Grünberg (MSC); Panama: Canal Zone, Albrook Forest Site, ground, collected by black light trap, 18.-19.4.1968, leg. R.S. Hutton (AMNH); 1 female, Cerro Campana, nr. Capira ( $\left.79^{\circ} 57^{\prime} \mathrm{W}, 8^{\circ} 44^{\prime} \mathrm{N}\right), 790 \mathrm{~m}$ elev., under bark, 18.5.1995, leg. J. S. Ashe \#021 (KNHM); female, Gamboa-Pipeline Rd. area, recently fallen tree, 1.6.1996, leg. S. Lingafelter (KNHM); 1 female, Hornito, Finca La Suiza $\left(82^{\circ} 12^{\prime} \mathrm{W}, 8^{\circ} 39^{\prime} \mathrm{N}\right), 1220 \mathrm{~m}$ elev., collected by flight intercept trap, 3.6.2000, leg. H. \& A. Howden (KNHM); Panama, Cerro Jeffe $\left(79^{\circ} 21^{\prime} \mathrm{W}, 9^{\circ} 12^{\prime} \mathrm{N}\right), 700 \mathrm{~m}$ elev. 16.1.1972, leg. Stockwell (BMNH); Venezuela: 2 males, 1 female, Carabobo, Mun. Bejuma, Quebrada, Aqua Clara $\left(61^{\circ} 24^{\prime} \mathrm{W}, 6^{\circ} 18^{\prime} \mathrm{N}\right), 300 \mathrm{~m}$ elev., leg. Wachtel \& L. Brachat (VAC, UIC); Guyana: 3 males, 3 females, Region 8, Iwokrama Forest, Pakatau hills $\left(59^{\circ} 01.36^{\prime} \mathrm{W}, 4^{\circ} 44.54^{\prime} \mathrm{N}\right), 70 \mathrm{~m}$ elev., under bark, 28.5.2001, leg. R. Brooks \& Z. Falin \#GUY1BF01052 (KNHM, UIC); French Guiana: male, Saül, 7 km N, Les Eaux Claires (53²13.19'W, 3³9.46'N), $220 \mathrm{~m}$ elev. fungusy $\log , 31.5 .1997$, leg. J. S. Ashe \& R. Brooks \#FG1AB97094 (KNHM); Suriname: 2 female, Saramacca, West Suriname Road, 108 km WSW Zanderij

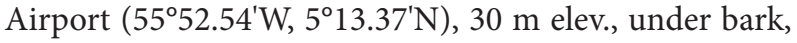
9.6.1999, leg. Z. H. Falin \#SUR1F99044 (KNHM); Ecuador: male, Pastaza Prov., Kapawi (7649.12'W, 2³3'S), collected by Malaise trap, 20.-28.3.1996, leg. P. Hibbs \#ECU2H96006A (KNHM).

Diagnosis: G. crassicorne is characterised by the deeply sculptured pronotum with shiny surface. The surface of the head is partly covered by a weak isodiametric microsculpture. The distinctness of the head microsculpture slightly varies between the specimens. But the surfaces of the head and the pronotum are always shiny. Considering the slight variance in the microsculpture, no differences could be found between SHARP's G. cribellum and Erichson's G. crassicorne. Therefore, G. cribellum is synonymised to G. crassicorne, although the type specimens of $G$. crassicorne are all females and, thus, a comparison between the aedeagi could not be performed. The differences in size mentioned by SCHEERPELTz (1970) cannot be confirmed. The type specimens of G. crassicorne are $2.8 \mathrm{~mm}$ long and not $3.25 \mathrm{~mm}$ as published by SCHEERPELTz (1970). G. crassicorne extremely resembles G. lescheni spec. nov. in size, deep ground sculpture of 
the pronotum, and the aedeagus. The two species can be distinguished by the distinct microsculpture of the head and pronotum in $G$. lescheni spec. nov.

Description: Length: $2.5-2.8 \mathrm{~mm}$. Colouration: Black; antennae dark brown, legs slightly lighter brown.
Head: $0.30 \mathrm{~mm}$ long, $0.44 \mathrm{~mm}$ wide; prominent eyes large; 1.5 times as long as temples; temples cheek-like; narrowed to neck in short convex curve; posterior edge of head emarginate; sides in front of eyes shortly concave; then approximately parallel to base of antennae; clypeus short; narrowed in sinuate curve to anterior edge; anterior margin $1 / 3$ as wide as width between base of antennae;

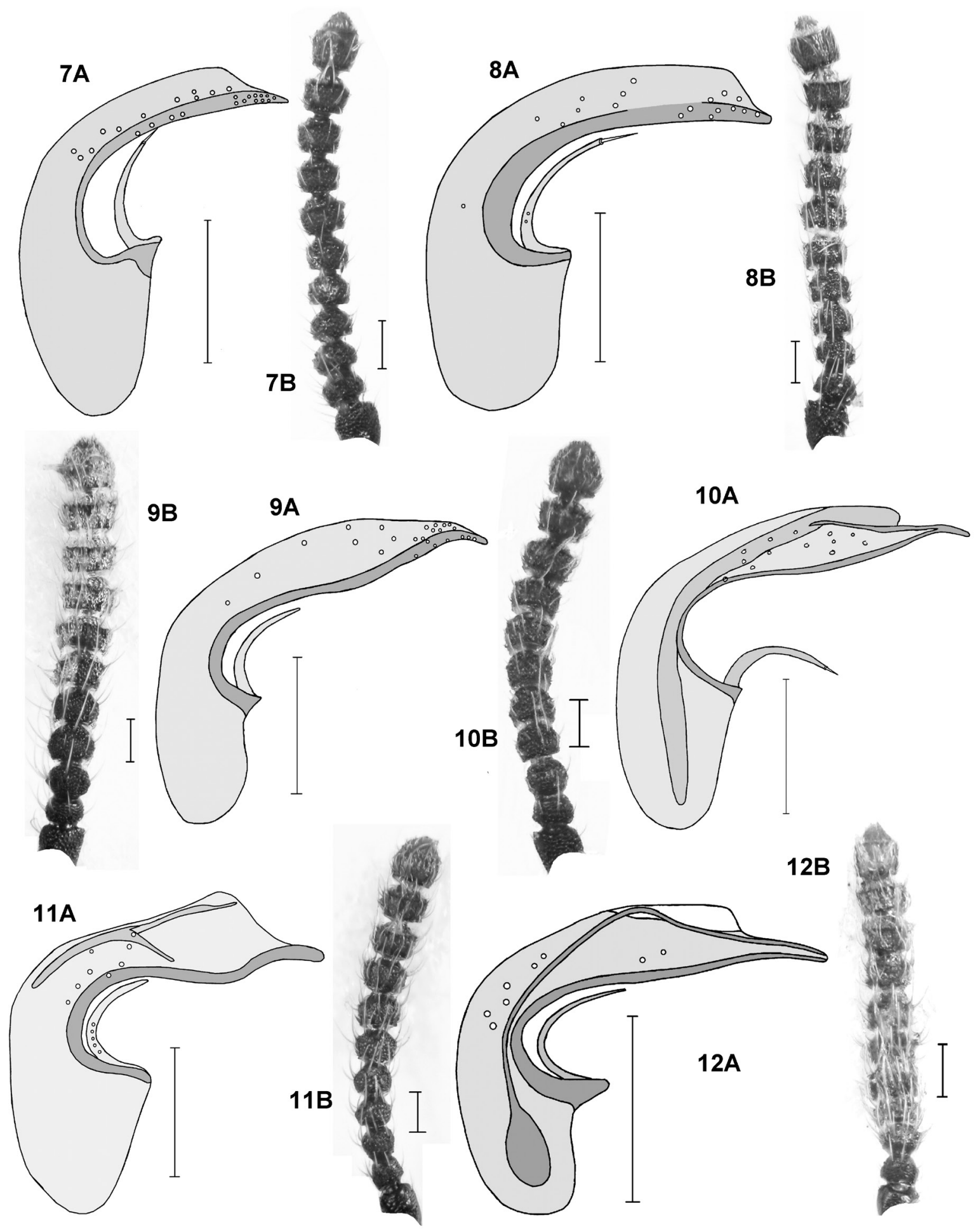

Figs 7-12: Aedeagus (A) and antenna (B) of Glyptoma crassicorne (7), G. lescheni (8), G. guianense (9), G. amazonense (10), G. guadelupense (11), G. hirticorne (12); scale bar: $0.1 \mathrm{~mm}$. 
setiferous punctation dense and extremely deep; on average, interstices between punctures less than half as wide as diameter of punctures; extremely weak microsculpture; close to neck isodiametric and slightly denser; surface shiny.

Antennae slightly longer than head and pronotum combined; first antennomere slightly thicker than second; second antennomere twice as wide as long; following antennomeres as wide as second and wider than long; penultimate antennomeres slightly longer than basal antennomeres; only slightly wider than long; all antennomeres with few long yellow setae; setae maximum as long as length of antennomere.

Pronotum: $0.37 \mathrm{~mm}$ long, $0.43 \mathrm{~mm}$ wide; widest at middle; narrowed to anterior obtuse angles in smooth convex curve; posterior half deeply emarginate; posterior edge not wider than width of mesonotum; interstices between pseudo-punctures reduced to narrow ridges; partly coriaceous; setiferous punctation on ridges between deep and coarse pseudo-punctures; microsculpture weak or absent; surface shiny.

Elytra: $0.59 \mathrm{~mm}$ long, $0.55 \mathrm{~mm}$ wide; sides smoothly rounded from shoulders to posterior angles; widest near middle; shoulders distinct, but obtusely rounded; discal carinae distinct from anterior margin to posterior margin; lateral carinae absent; pseudo-punctures on pronotum less deep than on pronotum; in area between suture and discal carina three irregular longitudinal rows of pseudo-punctures; inner row directly adjacent to suture; two irregular rows between discal carina and line from shoulders to posterior angles; interstices between pseudo-punctures restricted to narrow ridges; surface of pseudo-punctures and ridges with dense and deep microsculpture; setiferous punctation on ridges; surface totally matt.

Abdomen with similar large and dense pseudo-punctures as on elytra; pseudo-punctures equal on all segments; interstices between pseudo-punctures reduced to extreme narrow ridges; setiferous punctation on ridges between grooves; surface with dense and deep isodiametric microsculpture; matt.

Aedeagus strongly curved; angle between basal and apical lobe obtuse; nearly rectangular; apex acute; sides of apical lobe with numerous sensillae; sensillae denser at apex than close to basal lobe; paramere thin and short; only reaching half of apical lobe.

\section{Glyptoma guadelupense (WENDELER, 1930)}

(Figs 11A, B, 21E)

Calocerus guadelupensis Wendeler, 1930: 182

Type material examined: 1 male, 2 female syntypes: Guadeloupe: Trois Riviere, without further data, leg. Dufeau, (ZMHU).
Diagnosis: Among the species of the G. crassicorne-group, G. guadelupense (WENDELER, 1930) is characterised by the short elytra that are wider than long. Moreover, the pseudo-punctures of the elytra are combined to large deep impressions covered by a wide netlike microsculpture. In contrast to the other species of the group, the head is without microsculpture and shiny. The apical lobe of the aedeagus is widened in the apical half similar as in G. amazonense spec. nov. But sensillae were only found in the basal half, whereas in G. amazonense spec. nov. they were found in the apical half.

Description: Length: $2.4 \mathrm{~mm}$; Colouration: Dark brown, elytra slightly lighter brown; legs still lighter yellowish brown.

Head: $0.40 \mathrm{~mm}$ long, $0.45 \mathrm{~mm}$ wide; eyes small; not prominent; temples 1.5 times as long as eyes; supraocular groove from posterior edge of eyes to neck; sides in front of eyes parallel up to base of antennae; parallel part twice as long as length of eyes; then angulate in nearly rectangular angle; narrowed to anterior edge of clypeus in deep concave curve; anterior edge of clypeus half as wide as distance between base of antennae; setiferous punctation moderately deep; interstices between punctures ranging from as wide as diameter of punctures to three times as wide as diameter; clypeus with weak transversely striate microsculpture; vertex without microsculpture; surface polished.

Antennae as long as head and pronotum combined; all antennomeres approximately equally wide; second and third antennomere quadrate; fourth nearly twice as wide as long; following antennomere 1.5 times wider than long; second to tenth antennomere with long yellow setae; setae nearly as long as width of antennomeres.

Pronotum: $0.43 \mathrm{~mm}$ long, $0.47 \mathrm{~mm}$ wide; widest at anterior half; slightly narrowed in smooth convex curve to anterior angles; anterior angles obtusely rounded; narrowed to posterior angles in deep concave curve; posterior angles obtusely rounded; pseudo-punctures extremely deep and large; in most parts coriaceous; interstices between punctures restricted to narrow ridges; at midline with two pairs of pseudo-punctures; each pair nearly combined to one pseudo-puncture separated only by very low and narrow ridge at base; anterior pair smaller than posterior pair; very few setiferous punctures on ridges between pseudo-puncture; surface of pseudo-punctures with coarse widely meshed netlike microsculpture; surface of ridges without microsculpture; surface moderately shiny.

Elytra: $0.48 \mathrm{~mm}$ long, $0.52 \mathrm{~mm}$ wide; widest close to posterior margin; slightly narrowed to shoulders; shoulders smoothly rounded to deeply sinuate anterior edge; discal carina distinct; irregularly sinuate; lateral carina weaker and partly cut by large pseudo-punctures; broad suture stripe deeply impressed; continued to posterior margin; between suture stripe and discal carina with one longitudinal line of four to five large pseudo-punctures; between discal carina and lateral carina irregular pattern 
of pseudo-punctures; interstices between pseudopunctures restricted to extremely narrow ridges; partly, pseudo-punctures combined to larger pattern of deep grooves; few setiferous punctures on ridges between pseudo-punctures; surface of suture stripe and pseudopunctures with coarse deep netlike microsculpture; surface of ridges and carinae without microsculpture; surface moderately matt.

Abdomen at base of segments with transverse row of deep large pseudo-punctures forming irregular transverse grooves; at posterior edge of segments another narrow transverse impression; on ridges between pseudo-punctures few setiferous punctures; with similar coarse and deep microsculpture as fore-body; surface moderately matt.

Aedeagus angulate between basal and apical lobe; angle obtuse; apical lobe broad; ventral edge of apical lobe deeply sinuate; few sensillae at base of apical lobe and on thin paramere; paramere reaching only basal third of apical lobe.

\section{Glyptoma guianense spec. nov.}

(Figs 9A, B, 21C)

Type material: male, Holotype: Guyana: Region 8, Iwokrama Forest, 26 km SW Kurupukari, Iwokrama Mt. base camp $\left(58^{\circ} 48.38^{\prime} \mathrm{W}, 4^{\circ} 20.17^{\prime} \mathrm{N}\right)$, under bark, $60 \mathrm{~m}$ elev. 24.5.2001, leg. R. Brooks \& Z. Falin, \# GUY1BF01019 (KNHM). Paratypes: 1 female, 1 male, with same data as holotype; 1 female, same region, Kabocalli Field Stn. $\left(58^{\circ} 30.35^{\prime} \mathrm{W}, 4^{\circ} 17.4^{\prime} \mathrm{N}\right)$, under bark, $60 \mathrm{~m}$ elev., 5.6.2001, leg. R. Brooks \& Z. Falin, \#GUY1BF01140 (KNHM, UIC).

Diagnosis: Glyptoma guianense seems to be the sister species of G. amazonense spec. nov. regarding the very similar aedeagus and microsculpture. It differs in the less deep pseudo-punctures on head and pronotum. Furthermore, the temples of $G$. amazonense are more angulated, nearly rectangular, whereas they are convex in G. guiananense. Regarding the aedeagus, sensillae of the apical lobe of G. guianense are concentrated close to the apex, whereas in $G$. amazonense they are concentrated at the middle of the apical lobe.

Description: Length: 2.6-2.7 mm. Colouration: Black; legs and antennae dark brown; tarsi lighter brown.

Head: $0.39 \mathrm{~mm}$ long, $0.48 \mathrm{~mm}$ wide; eyes prominent; slightly shorter than temples; temples narrowed in smooth convex curve to neck; sides in front of eyes parallel up to base of antennae; parallel part nearly twice as long as eyes; narrowed anterior angle of clypeus in rectangular angles; anterior edge of clypeus one fourth as wide as distance between base of antennae; setiferous punctures large; on average, interstices between pseudo-punctures less than half as wide as diameter of punctures; setiferous punctures on ridges between pseudo-punctures; yellow setae as long as or longer than diameter of pseudo-punctures; clypeus without pseudo-punctures and setiferous punctures; isodiametric microsculpture deep and dense; on surface of pseudo-punctures and on ridges; setiferous punctures nearly invisible within deep microsculpture; surface totally matt.

Antennae slightly longer than head and pronotum combined; second antennomere slightly narrower than first; nearly twice as wide as long; following antennomeres as wide as first; third to eighth antennomere approximately 1.5 times as wide as long, ninth and tenth antennomere twice as wide as long; second to tenth antennomere with long yellow setae; penultimate antennomeres with denser setation than basal antennomeres; setae slightly longer than width of antennomeres.

Pronotum: $0.40 \mathrm{~mm}$ long, $0.45 \mathrm{~mm}$ wide; widest at middle; in anterior half, narrowed to anterior angles in smooth convex curve; anterior angles widely rounded; in posterior half, narrowed to posterior angles in concave curve; posterior angles shortly rounded; pseudo-punctures as large and dense as on head; on average, ridges between pseudo-punctures less than half as wide as diameter of pseudo-punctures; setiferous punctures inserting on ridges; yellow setae approximately as long as diameter of pseudo-punctures; at posterior angles with deep groove similar to pseudo-punctures, but more elongate, isodiametric microsculpture as deep and dense as on head; total surface matt.

Elytra: $0.59 \mathrm{~mm}$ long, $0.59 \mathrm{~mm}$ wide; sides smoothly rounded, but nearly parallel; shoulders distinct; nearly rectangular; anterior edge emarginate; discal carina distinct; lateral carina irregular and indistinct; suture line impressed; formed by small densely coriaceous punctures; continued to posterior margin; between suture line and discal carina several extremely large pseudo-punctures; partly coriaceous; interstices between pseudo-punctures restricted to small ridges; setiferous punctures on ridges; laterally to discal carina with more irregular and dense pseudo-punctures and setiferous punctation; microsculpture as dense and deep as on head and pronotum; on surface of pseudo-punctures more isodiametric, on surface of ridges more elongate; total surface matt.

Abdomen with one transverse row of pseudo-punctures; setiferous punctures restricted to small ridges between pseudo-punctures; posterior segments with denser setiferous punctation than anterior segments; isodiametric microsculpture as dense and deep as on fore-body; surface matt;

Aedeagus with obtuse angle between basal and apical lobe, apical lobe wider at middle than at base; close to apex sinuate; ending in acute apex; lateral sensillae densest at apex; sparser closely behind; paramere short; ending approximately at end of basal third of apical lobe.

Etymology: The species name derived from the country, where it was collected. 


\section{Glyptoma hirticorne SHARP, 1887}

(Figs 12A, B, 21F)

Glyptoma hirticorne SHARP, 1887: 724

Type material examined: 2 male, 3 female syntypes: Guatemala: Capetillo, leg. Champion (BMNH).

Diagnosis: G. hirticorne SHARP, 1887 is the smallest species of the group with pseudo-punctures on the pronotum. Concerning the shiny head and pronotum it resembles G. guadelupense (WENDELER, 1930). It can be easily identified by the distinctly convergent discal carinae of the elytra and by the dense setation of the antennomeres.

Description: Length: $2.3 \mathrm{~mm}$. Colouration: Dark brown to black; elytra slightly lighter, but still dark brown; legs lighter brown; tarsi yellowish.

Head: $0.30 \mathrm{~mm}$ long, $0.39 \mathrm{~mm}$ wide; eyes slightly prominent; as long as temples; temples narrowed to neck in smooth convex curve; sides in front of eyes parallel; parallel part slightly longer than eyes; angles at base of antennae widely rounded; narrowed to anterior edge of clypeus in sinuate curve; anterior edge of clypeus approximately half as wide as distance between base of antennae; setiferous punctation sparse and moderately deep; interstices between punctures irregular, but at least as wide as diameter of punctures; without microsculpture; surface shiny.

Antennae as long as head and pronotum combined; second and third antennomeres slightly narrower than following antennomeres; wider than long; fourth to tenth antennomere equally wide; tenth antennomere twice as wide as long; third to tenth antennomere covered by long yellow setae; setae slightly shorter than width of antennomere.

Pronotum: $0.32 \mathrm{~mm}$ long, $0.34 \mathrm{~mm}$ wide; widest near middle; narrowed to widely rounded anterior angles in smooth convex curve; narrowed to posterior obtusely angled angles in concave curve; pseudo-punctures large; symmetric on both side of midline; three closely adjacent pairs; smaller one in anterior half; larger and smaller one in posterior half; between anterior pair and larger posterior pair with moderately wide impunctate area; on remaining area, interstices between pseudo-punctures restricted to small ridges; at posterior angles combined to irregular impression; setiferous punctation on ridges between pseudo-punctures; surface of pseudo-punctures with netlike microsculpture; ridges with remnants of microsculpture; surface moderately shiny;

Elytra: $0.54 \mathrm{~mm}$ long, $0.48 \mathrm{~mm}$ wide; widest in middle, but approximately parallel; shoulders widely rounded to emarginate anterior edge; with discal carina distinct; lateral carina absent; discal carinae convergent anteriad; suture line narrow; continued to posterior margin; between suture line and discal carina with irregular pattern of pseudo-punctures; in posterior part partly coriaceous; laterad of discal carinae with rows of pseudo-punctures; interstices between pseudo-punctures irregular, but approximately half as wide as diameter of pseudo-punctures; setiferous punctation restricted to ridges; remnants of microsculpture longitudinally striate; laterad to discal carinae partly more distinct than between suture line and discal carinae; surface moderately shiny.

Abdomen densely covered by large pseudo-punctures; ridges between pseudo-puncture still narrower than on pronotum and elytra; on posterior segments sparser than on anterior segments; setiferous punctation on ridges between pseudo-punctures.

Aedeagus with nearly rectangular angle between basal and apical lobe, apical lobe abruptly narrowed to acute apex in apical third; close to apex sinuate; group of four sensillae at lateral base of apical lobe and two pairs of sensillae closer to apex; endophallus with obtuse angle at half of apical lobe; paramere short; ending approximately at end of basal third of apical lobe.

\section{Glyptoma lescheni spec. nov.}

(Figs 8A, B, 21B)

Type material: male, Holotype: Bolivia: Santa Cruz Dept., $3.7 \mathrm{~km}$ SSE Buena Vista Hotel Flora y Fauna $\left(63^{\circ} 33.15^{\prime} \mathrm{W}\right.$, $\left.17^{\circ} 29.95^{\prime} \mathrm{S}\right)$, Chiquitano for. leaf litter, $400-440 \mathrm{~m} \mathrm{elev.}$, 5.11.2002, leg. R. Leschen \#BOL1L02-021 (KNHM). Paratypes: 1 male, 9 females with same data as holotype (KNHM, UIC); Cochabamba, Cochabamba, $67.5 \mathrm{~km} \mathrm{NE,}$ Est. Biol. Valle del Sajita, Univ. de San Simon ( $64^{\circ} 47.52^{\prime} \mathrm{W}$, $\left.17^{\circ} 06.33^{\prime} \mathrm{S}\right), 300 \mathrm{~m}$ elev., collected by flight intercept trap, 1 male, 1 female, 9.-13.2.1999, leg. F. Genier \#BOL1G99068 (KNHM); Peru: Tambopata Prov., 15 km NE Pto., Maldonado, under bark, 200 m elev., 2 males, 3 females, 1.7.1989, leg. J. S. Ashe \& R. Leschen \#359 (KNHM, UIC); Madre de Dios, Pakitza Bio. Stn., Castanal Trail, Reserved Zone, Manu National Park $\left(71^{\circ} 17^{\prime} \mathrm{W}\right.$, $\left.11^{\circ} 56.41^{\prime} \mathrm{S}\right), 317 \mathrm{~m}$ elev. collected by flight intercept trap, male, 15.-16.10.2000, leg. R. Brooks \#PERU1B00013 (KNHM); Junin, San Ramon de Pagoa, 40 km S Satipo, 750 m elev., 6 males, 4 females, 29.1.1974, leg. R. T. Schuh (AMNH, UIC); Huanuco, Rio Llullapichis, Stat. Panguana (7456'W, 9³7'S), Nov.-Dec. 2008, leg. F. Wachtel (VAC); Columbia: Amazonas, PNN Amacayacu, San Martin $\left(70^{\circ} 18^{\prime} \mathrm{W}, 3^{\circ} 46^{\prime} \mathrm{S}\right), 150 \mathrm{~m}$ elev., collected by Malaise trap, male, 29.12.2000-6.1.2001, leg. B. Amado \# M1315 (KNHM).

Diagnosis: G. lescheni extremely resembles G. crassicorne ERICHSON, 1840. It seems to be the sister species of G. crassicorne ERICHSON, 1840 in the Pre-Andean region from southern Columbia to Bolivia. The two species can be easily distinguished by the matt surface of the head in G. lescheni compared to the shiny surface in G. crassicorne ERICHSON, 1840. The aedeagi of both species are also very similar. Up to date, I found no intermediate species between the northern G. crassicorne ERICHSON, 
1840 with shiny head and the southern $G$. lescheni with matt head. If such specimens can be found in future, it must be considered that both species are forming one population with high variance in the head and pronotum microsculpture.

Description: Length: 2.7-2.9 mm. Colouration: Black; antennae dark brown, legs slightly lighter brown.

Head: $0.30 \mathrm{~mm}$ long, $0.47 \mathrm{~mm}$ wide; prominent eyes large; 1.5 times as long as temples; temples narrowed to neck in short convex curve; posterior edge of head slightly emarginate; sides in front of eyes to base of antennae parallel; clypeus short; narrowed in sinuate curve to anterior edge; anterior margin $1 / 3$ as wide as width between base of antennae; setiferous punctation dense and extremely deep; on average, interstices between punctures slightly wider than diameter of punctures; isodiametric microsculpture deep; around deep punctures, microsculpture more elongate forming star-like patterns; surface matt.

Antennae slightly longer than head and pronotum combined; first antennomere slightly thicker than second; second and third antennomeres nearly twice as wide as long; following antennomeres as wide as second and wider than long; penultimate antennomeres slightly longer than basal antennomeres; only slightly wider than long; all antennomeres with long yellow setae; setae longer than length of antennomere; surface of antennomeres with deep isodiametric microsculpture.

Pronotum: $0.39 \mathrm{~mm}$ long, $0.49 \mathrm{~mm}$ wide; widest at middle; narrowed to anterior obtuse angles in smooth convex curve; posterior half deeply emarginate; posterior edge not wider than width of mesonotum; interstices between pseudo-punctures reduced to narrow ridges; partly coriaceous; setiferous punctation on ridges between deep and coarse pseudo-punctures; isodiametric microsculpture deep and dense restricted to surface of pseudo-punctures; on ridges, microsculpture weaker; surface matt; only surface of ridges slightly shiny.

Elytra: $0.60 \mathrm{~mm}$ long, $0.57 \mathrm{~mm}$ wide; sides smoothly rounded from shoulders to posterior angles; widest near middle; shoulders distinct, but obtusely rounded; discal carinae distinct from anterior margin to posterior margin; lateral carinae absent; pseudo-punctures as large as on pronotum, but less deep; in area between suture and discal carina three irregular longitudinal rows; inner row directly adjacent to suture; two irregular rows between discal carina and line from shoulders to posterior angles; interstices between pseudo-punctures restricted to narrow ridges; setiferous punctation on ridges between pseudo-punctures; with dense and deep isodiametric microsculpture; surface totally matt.

Abdomen with similar large and dense pseudo-punctures as on elytra; grooves equal on all segments; interstices between pseudo-punctures reduced to extreme narrow ridges; setiferous punctation on ridges between pseudopunctures; surface with dense and deep isodiametric microsculpture; matt.
Aedeagus strongly curved; angle between basal and apical lobe obtuse; nearly rectangular; short apex acute; sides of apical lobe with several sensillae; paramere thin and short; only reaching half of apical lobe.

Etymology: The species is named to honour the collector of the species Richard Leschen, who extensively collected in the Neotropics.

\section{Group of Glyptoma cognatum}

The species of the group are small, 1.8 to $3.2 \mathrm{~mm}$ length. The pronotal punctation is setiferous; punctures are coarse and deep, but no pseudo-punctures. The elytra are at least partly shiny.

\section{Glyptoma cognatum SHARP, 1887}

(Figs 16A, B, 22D)

Glyptoma cognatum SHARP, 1887: 724

Type material examined: Guatemala: 1 male, 1 female syntypes: El Reposo, leg. C. Champion (BMNH).

Further material examined: Panama: 1 male, Canal Zone, Albrook Forest Site, collected by black light (ground), 23.-24.5.1968, leg. R. Hutton (AMNH); 1 female, same location, $100 \mathrm{ft}$. elev., collected by black light, 16.5.1968, leg. R. Hutton (AMNH); French Guiana: 1 male, 2 females, Saül, under bark, March-April 1999, leg. A. Berkov (AMNH, UIC).

Diagnosis: The three species G. cognatum, G. denieri, and G. klimschi are very similar in size and shape of the aedeagus. G. cognatum can be differentiated from the two other species by the intermediate size from the slightly larger $G$. denieri and the slightly smaller G. klimschi. Regarding the microsculpture of the head and pronotum as well as both the thin apical lobe and few sensillae of the aedeagus, it resembles G. denieri. However, the microsculpture of G. cognatum is weaker than in G. denieri and the number of punctures in the posterior half of the elytra is lower. In contrast to $G$. denieri, the apex of the aedeagus of G. cognatum is curved pointing ventrad, whereas it is more or less straight in $G$. denieri.

Description: Length: 2.1-2.2 mm. Colouration: Dark brown; elytra lighter red; legs still lighter, yellowish.

Head: $0.27 \mathrm{~mm}$ long, $0.40 \mathrm{~mm}$ wide; eyes slightly prominent; nearly twice as long as temples; temples narrowed to neck in short strongly convex curve; sides in front of eyes parallel up to base of antennae; parallel part as long as length of eyes; at base of antennae abruptly narrowed to anterior edge of clypeus in nearly rectangular angle; anterior edge of clypeus slightly shorter than distance between base of antennae; setiferous punctures deep 
and moderately dense; interstices between punctures ranging between twice and three times as wide as diameter of punctures; close to neck, punctation denser; with weak irregular microsculpture; partly longitudinally striate; partly transversely striate; surface moderately shiny.
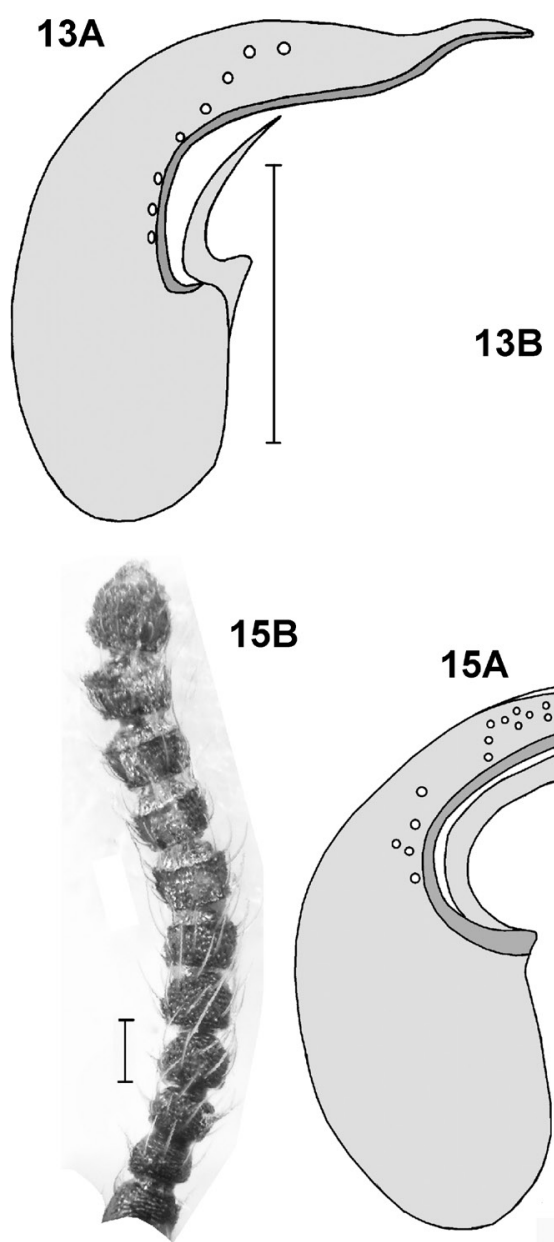

15B
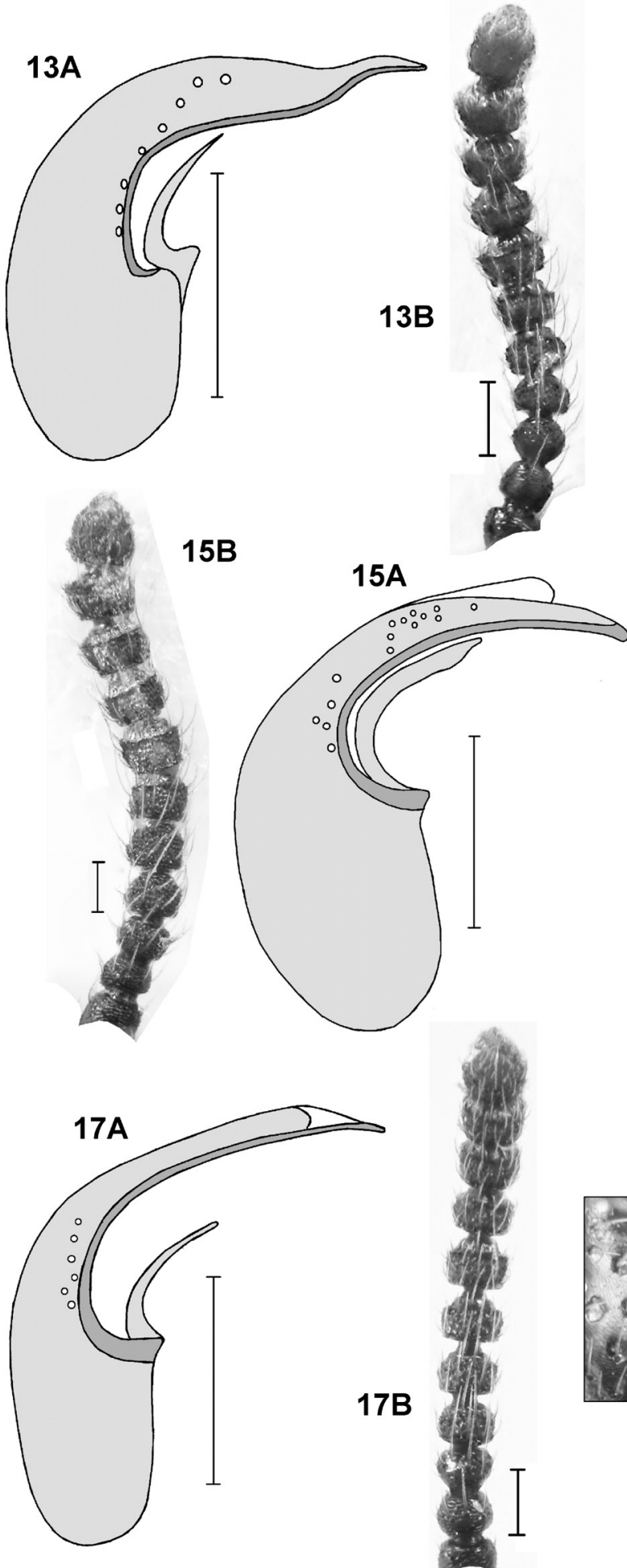

Antennae as long as head and pronotum combined; all antennomeres nearly equally wide; second antennomere nearly twice as wide as long; third to fifth antennomere approximately 2.5 to 3 times as wide as long; tenth antennomere again twice as wide as long; second to tenth antennomere with long yellow setae; on average, setae approximately as long as half of width of antennomeres.
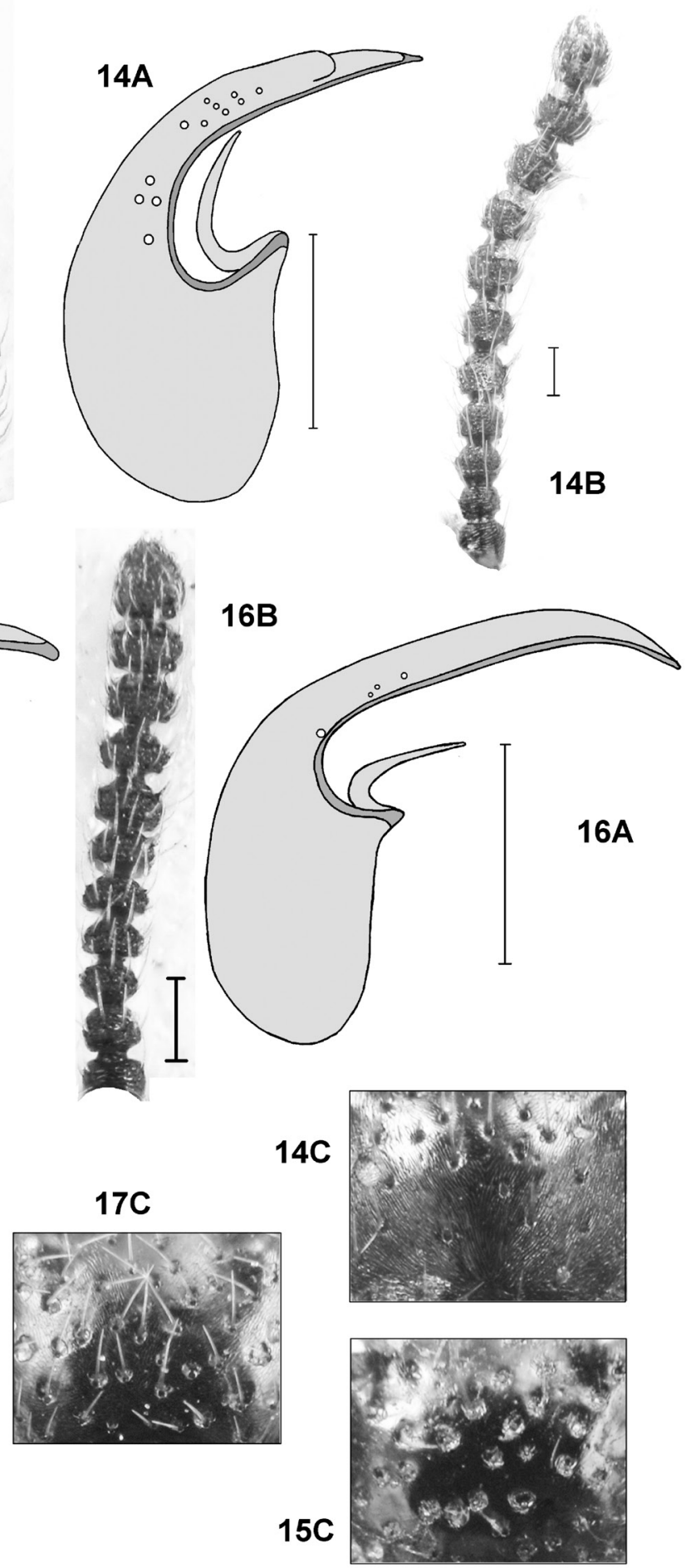

Figs 13-17: Aedeagus (A), antenna (B) and microsculpture of head (C) of Glyptoma nitidum (13), G. obscuricolle (14), G. nitens (15), G. cognatum (16), G. denieri (17); scale bar: $0.1 \mathrm{~mm}$. 
Pronotum: $0.29 \mathrm{~mm}$ long $0.35 \mathrm{~mm}$ wide; widest at anterior third; narrowed to anterior angles in short convex curve; narrowed to posterior angles in long, slightly concave curve; anterior and posterior angles obtuse; front edge slightly prominent; posterior edge as wide as neck; setiferous punctures large, but size irregular; partly coriaceous; on average, interstices between punctures mostly restricted to very narrow ridges; at posterior angles with irregular elongate impression; narrow midline impunctate; disc bordered by indistinct, irregularly sinuate carinae; insertion of setae partly centric, partly eccentric; microsculpture weak; longitudinally striate; surface shiny. Elytra: $0.48 \mathrm{~mm}$ long, $0.45 \mathrm{~mm}$ wide; sides smoothly rounded; nearly parallel; shoulders distinct; shortly rounded to emarginate anterior edge; suture line formed by densely coriaceous small punctures; continued to posterior margin; discal carina distinct; lateral carina absent or only partly developed; discal carina margined at inner and outer edge by longitudinal row of elongate setiferous punctures; in anterior half on area between suture line and discal carina, several setiferous punctures; in posterior half impunctate; laterad to discal carina three longitudinal rows of setiferous punctures; extremely weak microsculpture; longitudinally striate; surface shiny.

Abdomen on segments III to VI with two transverse irregular rows of large setiferous punctures; posterior half of segments III to VI with impunctate area; without microsculpture; surface shiny.

Aedeagus angulate between basal and apical lobe; angle obtuse; apical lobe narrow ending in acute apex; apex shortly curved; pointing ventrad; very few small sensillae at base of apical lobe; paramere reaching end of basal third of apical lobe.

\section{Glyptoma denieri (BERNHAUER, 1939)}

(Figs 17A B, C, 22E)

Calocerus denieri Bernhauer, 1939: 232

Calocerus sanctaecatharinae SCHEERPELTz, 1970: 13 new synonymy

Type material examined: Glyptoma denieri: 1 male, holotype: Argentina: Salta, 28.6.1933, leg. Denier (FMNH). C. sanctaecatharinae Scheerpeltz, 1970: 2 female syntypes: Brazil: Santa Catharina, leg. Klimsch (NHMW).

Further material examined: Argentina: 1 female, Salta Prov., Aguas Blancas-Yaculica, (Argentina-Bolivian frontier) $\left(64^{\circ} 23.52^{\prime} \mathrm{W}, 22^{\circ} 42.38^{\prime} \mathrm{S}\right)$, Yungas forest leaflitter, $520 \mathrm{~m}$ elev., leg. J. Carpenter \& D. Agosti (AMNH); Brazil: 2 males, 4 females, Santa Catharina, Blumeau, 1889, leg. A. Hetschko (NHMW); 1 female, São Paulo, without further data, coll. Cameron (BMNH); 1 male, 1 female, Rio de Janeiro, Itatiaia, Fazenda da Serra, 22.5.1960, leg. H. Schubart \& J. Becker (UIC); 1 female, Rio de Janeiro, Floresta de Tijuca, 17.7.1960, leg. H. Schubart (UIC); Rio de Janeiro, without further data, coll. Cameron (BMNH);
Brasilia, coll. Kraatz, without further data (SDEI); Paraguay: 1 female, Cazaapa, Hermosa, prop. Sosa family,

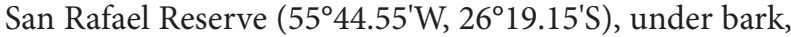
$90 \mathrm{~m}$ elevation, 4.12.2000, leg. Z. Falin \#PAR1F00105 (KNHM)

Diagnosis: The holotype of G. denieri was the only male specimen that could be studied from Argentina. The pattern of punctation slightly differs from the Brazilian and Paraguayan specimens in punctation of the area between suture line and discal carina. In contrast to the Brazilian and the Paraguayan specimens, the type specimen from Argentina has one more puncture in the overlapping zone between the irregular punctation of the anterior half and the row of punctures of the posterior half. However, the pattern and number of punctures of the anterior punctation varies considerably between the specimens. It seems not to be a specific character. Thus, G. sanctaecatharinae is synonymised, in particular, as no differences were found in the aedeagus between the Brazilian and the Paraguayan specimens and the Argentinean type. In addition to the differentiating characters described under G. cognatum and G. klimschi, G. denieri also resembles $G$. obscuricolle in the denser microsculpture of the fore-body. However, G. denieri is distinctly smaller than G. obscuricolle and the microsculpture is weaker. In contrast to G. obscuricolle, the apical lobe of the aedeagus is longer and thinner and has fewer sensillae.

Description: Length: $2.4 \mathrm{~mm}$. Colouration: Brown; elytra slightly lighter reddish brown; legs still lighter; yellowish brown;

Head: $0.36 \mathrm{~mm}$ long, $0.48 \mathrm{~mm}$ wide; eyes slightly prominent; twice as long as temples; temples narrowed to neck in short convex curve; cheek-like; in front of eyes, sides parallel up to base of antennae; parallel part approximately as long as length of eyes; then abruptly narrowed to anterior edge of clypeus in sinuate curve; anterior edge of clypeus 2.5 times as wide as distance between base of antennae; setiferous punctation deep and moderately dense; on vertex denser than on clypeus; on clypeus, interstices between punctures twice as wide as diameter of punctures; on vertex, interstices between punctures approximately as wide as diameter of punctures; setae at least as long as interstices between punctures; microsculpture weak; transversely or longitudinally striate; surface moderately shiny.

Antennae as long as head and pronotum combined; all antennomeres nearly equally wide; slightly wider than long; second to tenth antennomere with long yellow setae; setae at least as long as width of antennomeres.

Pronotum: $0.37 \mathrm{~mm}$ long, $0.43 \mathrm{~mm}$ wide; widest in anterior third; in anterior third slightly narrowed to nearly rectangular angles; anterior edge slightly prominent; in posterior two third, sides narrowed to posterior angles in concave curve; posterior angles obtusely rounded; setiferous punctation deep and moderately dense; size of punctures varying; interstices between punctures at 
least as wide as diameter of punctures; lateral punctation denser than discal punctation; partly coriaceous; posterior angles with elongate deep grooves; moderately deep microsculpture longitudinally striate; surface slightly shiny.

Elytra: $0.62 \mathrm{~mm}$ long, $0.55 \mathrm{~mm}$ wide; sides slightly curved, but nearly parallel; shoulders rounded; anterior edge slightly emarginate; discal carina distinct; lateral carina absent; suture line formed by dense small punctures; continued to posterior margin; between suture line and discal carina with irregular setiferous punctures in anterior half and longitudinal row of 5 to 6 setiferous punctures in posterior half close to discal carina; at outer side of discal carina, dense row of elongate setiferous punctures; laterad with additional rows of elongate setiferous punctures; partly irregular in posterior half and with additional punctures between rows; microsculpture weak; netlike on surface of punctures; densely elongate on surface between punctures; surface slightly shiny.

Abdomen on segments III to VI with two transverse irregular rows of large setiferous punctures; in posterior middle of segments III to VI with impunctate area; with weak microsculpture; surface shiny.

Aedeagus angulate between basal and apical lobe; angle obtuse; apical lobe narrow ending in acute apex; apex shortly curved; pointing ventrad; irregular row of sensillae at base of apical lobe; paramere reaching end of basal third of apical lobe.

\section{Glyptoma klimschi (BERNHAUER, 1908)}

(Figs 18A, B, 22F)

Calocerus klimschi Bernhauer, 1908: 285

Type material examined: female, holotype: Brazil: Santa Catarina, leg. Klimsch (FMNH).
Further material examined: Guyana: 1 female, Region 8, Iwokrama Forest, $1 \mathrm{~km}$ W Kurupukari, Iwokrama Field. Stn. $\left(58^{\circ} 41.4^{\prime} \mathrm{W}, 4^{\circ} 40.19^{\prime} \mathrm{N}\right)$, under bark, $60 \mathrm{~m}$ elev. 2.6.2001, leg. R. Brooks \& Z. Falin \#GUY1BF01121 (KNHM); Maroni, without further data (BMNH); French Guiana: 2 females, Matoury, $41.9 \mathrm{~km}$ SSW on Hwy. N2 $\left(52^{\circ} 24.17^{\prime} \mathrm{W}, 4^{\circ} 34.51^{\prime} \mathrm{N}\right)$, under bark, $125 \mathrm{~m}$ elevation, 28.5.1997, leg. J. Ashe \& R. Brooks \#FG1AB97068 (KNHM); 3 males, 7 females, Saül, under bark, 3.-4.1999, leg. A. Berkov (AMNH, UIC); Bolivia: 1 male, Santa Cruz Dept., 3.7 km SSW Buena Vista Hotel Flora y Fauna $\left(63^{\circ} 33.15^{\prime} \mathrm{W}, 17^{\circ} 29.95^{\prime} \mathrm{S}\right)$, Chiquitano forest leaf litter, 400-440 m elevation, 5.11.2002, leg. R. Leschen \#BOL1L02-021 (KNHM); 1 female, Cochabamba Prov., Cochabamba, $67.5 \mathrm{~km}$ NE Est. Biol. Valle del Sajita, Univ. de San Simon $\left(64^{\circ} 47.52^{\prime} \mathrm{W}, 17^{\circ} 06.33^{\prime} \mathrm{S}\right)$, collected by flight intercept trap, 300 m elevation, 7.-9.2.1999, leg. R. Hanley \#BOL1H99057 (KNHM).

Diagnosis: G. klimschi is the smallest species among the similar species listed under the G. cognatum-group. It can be identified by the shiny head. The microsculpture of the head of G. cognatum and G. denieri is more distinct and surface, thus, less shiny. Moreover, the apical lobe of the aedeagus is thicker and has numerous sensillae, in particular, at apex, whereas the apical lobe of the aedeagus in G. cognatum and $G$. denieri has only few sensillae.

Description: Length: $1.85 \mathrm{~mm}$. Colouration: Dark reddish brown; elytra lighter reddish; legs still lighter; yellowish.

Head $0.25 \mathrm{~mm}$ long, $0.35 \mathrm{~mm}$ wide; eyes slightly prominent; slightly shorter than temples; temples smoothly rounded to neck in convex curve; sides in front of eyes up to base of antennae parallel; parallel part approximately as long as length of eyes; in front of antennal base angu-
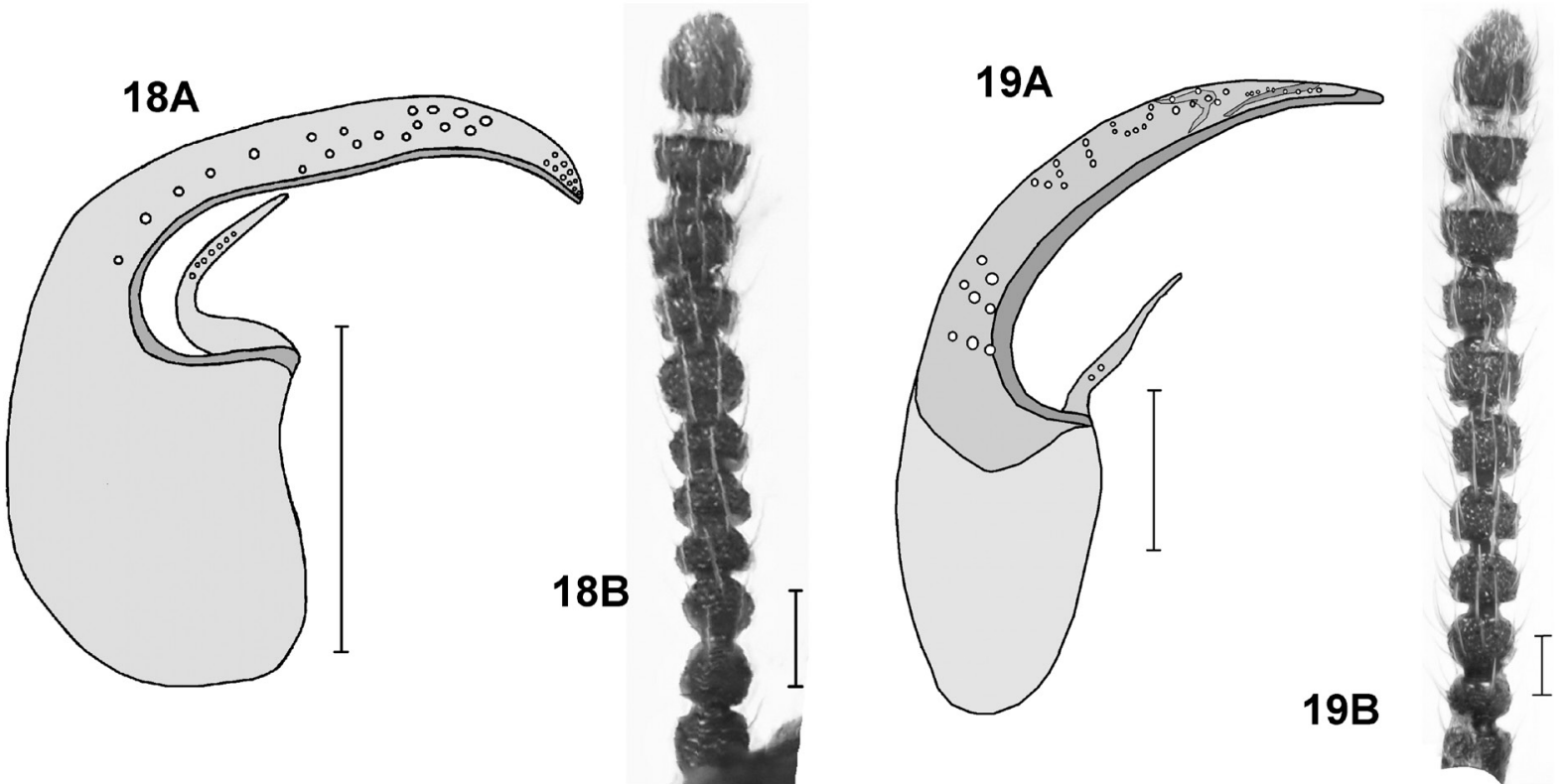

Figs 18-19: Aedeagus (A) and antenna (B) of Glyptoma klimschi (18), G. schuhi (19); scale bar: $0.1 \mathrm{~mm}$. 
late in nearly rectangular angle; sinuate to anterior edge of clypeus in concave curve; anterior width of clypeus slightly shorter than distance between base of antennae; setiferous punctation deep and moderately dense; punctures on disc larger than on clypeus; interstices between punctures varying, but at least as wide as diameter of punctures; with remnants of weak microsculpture; surface shiny.

Antennae as long as head and pronotum combined; all antennomeres approximately equally wide; second antennomere approximately quadrate; third to tenth antennomere slightly wider than long; second to tenth antennomere with few long yellow setae; setae as long as or slightly longer than width of antennomeres.

Pronotum: $0.35 \mathrm{~mm}$ long $0.27 \mathrm{~mm}$ wide; widest at anterior third; narrowed to anterior angles in short convex curve; anterior angles obtuse; front edge smoothly prominent; in posterior two third, narrowed to posterior angles in concave curve; posterior angles obtuse; posterior edge as wide as neck; disc with large setiferous punctures; size of punctures varying; lateral punctures very dense; partly coriaceous; forming irregular elongate impressions; two larger punctures at middle in front of posterior edge; on disc of anterior half with transverse impunctate area; surface of punctures with netlike microsculpture; interstices between punctures with remnants of weak longitudinally striate microsculpture; surface shiny.

Elytra: $0.45 \mathrm{~mm}$ long, $0.37 \mathrm{~mm}$ wide; sides slightly convex, but nearly parallel; shoulders rounded to emarginate anterior edge; discal carina distinct; lateral carina absent; suture line marked by line of close small punctures; continued to posterior margin; on area between suture line and discal carina with two short lines of setiferous coriaceous punctures; one slightly diagonal line in anterior half and one longitudinal row close to discal carina in posterior half; both lines overlapping at middle; laterad to discal carina with line of setiferous coriaceous punctures partly forming elongate impressions; laterad further rows of coriaceous punctures; with remnants of weak longitudinally striate microsculpture; surface shiny.

Abdomen on each abdominal segment with irregular transverse rows of large setiferous punctures; punctures much larger than on the pronotum; interstices on segments III to VII restricted to small ridges; posteriad to middle of segments III to VII with impunctate area; weak microsculpture netlike; surface shiny.

Aedeagus obtusely angulate between basal and apical lobe; apical lobe slightly curved; ending in acute apex; apex shortly curved; pointing ventrad; dense group of sensillae at apex; numerous sensillae from base of apical lobe to close to apex; paramere slightly longer than basal third of apical lobe; with several sensillae.

\section{Glyptoma nitens (BERNHAUER, 1908)}

(Figs 15A, B, C, 22C)

Calocerus nitens BernHAUER, 1908: 284

Calocerus reichenspergi SCHEERPELTZ 1970, 135 new synonymy

Type material examined: male, Holotype: Brazil: São Paulo, leg. A. Barbiellini (FMNH).

G. reichenspergi Scheerpeltz, 1970: 1 female syntype: São Paulo, Mogy das Cruzes, 1.5.1917, leg. J. Mráz (NHMW); 1 female syntype of $G$. reichenspergi, Blumenau, leg. P. Witte (NHMW).

Further material examined: Brazil: São Paulo, 31 specimens, leg. J. Mráz (MNHP, AMNH, UIC); Rio de Janeiro, Floresta da Tijuca, 6 males, 8 females, 17.07.1960, leg. H. Schubart (UIC); same location, 1 male, 6 females, 17.03.1962, leg. J. Becker \& H. Schubart (UIC); same location, 2 females, 1.8.1960, leg. H. Schubart (UIC); same location, 1 female, Caminho do Rio do Papageio, 16.7.1959, leg. H. Schubart (UIC); same location, 1 female, Estrada do Sumaré, 6.7.1960, leg. H. Schubart (UIC).

Diagnosis: The species resembles G. nitidum (BERNHAUER, 1908) by its shiny surface. But G. nitens is larger and the elytral punctures are more numerous and much coarser. ScheERPELTz (1970) published that $G$. reichenspergi should be $3.25 \mathrm{~mm}$ long. My own measurements of the two syntypes of $G$. reichenspergi revealed a length of $2.8-2.9 \mathrm{~mm}$. I found no other characters to distinguish G. reichenspergi from G. nitens. Therefore, I synonymise $G$. reichenspergi with $G$. nitens.

Description: Length: 2.6-2.9 mm, Colouration: Brown, elytra reddish, legs light brown.

Head: $0.40 \mathrm{~mm}$ long, $0.50 \mathrm{~mm}$ wide; eyes slightly prominent; as long as temples; temples smoothly rounded to neck; sides in front of eyes up to base of antennae parallel; parallel part slightly longer than length of eyes; then, abruptly narrowed in sinuate curve to anterior edge of clypeus; width of anterior edge of clypeus half as wide as width between base of antennae; setiferous punctation dense and coarse; interstices between punctures less than half as wide as diameter of punctures; on vertex partly wider; without microsculpture; surface polished.

Antennae as long as head and pronotum combined; all antennomeres equal in width; only second antennomere slightly narrower than the following; second antennomere nearly twice as wide as long, third antennomere wider than long, but nearly quadrate; penultimate antennomeres slightly less than twice as wide as long; antennomere two to ten with long yellow setae; setae approximately as long as width of antennomeres.

Pronotum: $0.40 \mathrm{~mm}$ long, $0.50 \mathrm{~mm}$ wide; widest in anterior third; narrowed to anterior edge in smooth convex curve; anterior edge also slightly prominent in convex curve; in posterior half narrowed to posterior angles in 
deep concave curve; setiferous punctation coarse and deep; partly coriaceous; laterally denser than on disc; in middle of disc with smaller punctures and with varying large impunctate area; surface of punctures with coarse isodiametric microsculpture; remaining surface without microsculpture; impunctate areas on disc and ridges between punctures polished; lateral and posterior parts less shiny.

Elytra: $0.60 \mathrm{~mm}$ long, $0.60 \mathrm{~mm}$ wide; widest in posterior third; sides smoothly rounded; shoulders obtuse, but distinct; anterior edge slightly concave; discal carina distinct; posteriad more or less distinctly curved; pointing to suture; lateral carina indistinct; suture line consisting of small dense partly coriaceous punctures continuing to posterior edge; between suture line and discal carina two irregular rows of setiferous punctures; between discal carina and lateral carina two rows of setiferous punctures; punctation denser and more regular than between suture and discal carina; setiferous punctures large and with isodiametric microsculpture; remaining surface without microsculpture; polished.

Abdomen with transverse rows of large setiferous punctures; punctures as large as on elytra; surface of setiferous punctures with isodiametric microsculpture, in particular, in punctures at base of each abdominal segment; surface between punctures polished.

Aedeagus smoothly curved from basal to apical lobe; continuously narrowed to apex; apex shortly rounded; apical lobe with numerous sensillae from apical third to near base; paramere reaching middle of apical lobe.

\section{Glyptoma nitidum (BERNHAUER, 1908)}

(Figs 13A, B, 22A)

Calocerus nitidus Bernhauer, 1908: 284

Calocerus bolivianus SCHEERPELTZ, 1970: 141 new synonymy

Glyptoma trinidadense BLACKWELDER, 1943: 141 new synonymy

Type material examined: female, holotype: Paraguay: without further data, leg. Drake (FMNH).

Calocerus bolivianus SCHeERPELTz. 1970: Bolivia: 1 female syntype; 2 males, 13 females syntypes, labelled as cotypes; Region Chaparé, 400 m elevation, 14.8.1954, leg. R. Zischka (NHMW).

Glyptoma trinidadense BLACKWELDER, 1943: 2 male paratypes: Trinidad: Port of Spain, Blackwelder Sta. \#109 (61ํ3' W, 1044'N), 27.12.1935, leg. R. Blackwelder (BMNH).

Further material examined: Peru: 1 male, Dept. Ucayali, $60 \mathrm{~km}$ W Pucalpa, Estacion IVITA, Remiza-2, under bark, 25.6.1986, leg. A. Zakharov (UIC); female, Prov. Huanuco, Rio Llullapichis, Panguana, Res. St., pasture with Pueraria phaseoloides, 12.6.1975, leg. W. Hanagarth (UIC); 1 male, 1 female, same location, 10.-24.10.1984 and 8.11.-6.12.1984, leg. M. Verhaagh \#GuU18, \#GuU12
(UIC); 1 male, 2 females, same location $\left(74^{\circ} 56^{\prime} \mathrm{W}\right.$, $\left.9^{\circ} 37^{\prime} \mathrm{S}\right)$, collected at light, 2.-20.10.2000, leg. G. Riedel (VAC, UIC); 1 male, Loreto, km 3 Tournavista Rd., 34 km W Pucallpa, $300 \mathrm{~m}$ elev., 17.12.1971, leg. R.T. \& J.C. Schuh (AMNH); Bolivia: 3 males, 1 female, Dept. Santa Cruz, 3.7 km SSE Buena Vista, Hotel Flora y Fauna $\left(63^{\circ} 33.15^{\prime} \mathrm{W}, 17^{\circ} 29.95^{\prime} \mathrm{S}\right)$, secondary forest, collected by flight intercept trap, 400-440 m elev., 2.-9.11.2002, leg., R. Leschen \#BOL1L02-055 (KNHM, UIC); Guyana: 1 female, Region 8, Iwokrama Forest, Pakatau hills $\left(59^{\circ} 0136^{\prime} \mathrm{W}, 4^{\circ} 44.54^{\prime} \mathrm{N}\right)$, under bark, $70 \mathrm{~m}$ elev., 28.5.2001, leg. R. Brooks \& Z. Falin \#GUY1BF01952 (KNHM); French Guyana: 1 male, 1 female, Caussade $\left(52^{\circ} 35.29^{\prime} \mathrm{W}\right.$, $\left.5^{\circ} 03.57^{\prime} \mathrm{N}\right)$, collected by car net, 6.11 .2011 , leg. T. Struyve (UIC); 3 females, Saül $\left(53^{\circ} 12^{\prime} \mathrm{W}, 3^{\circ} 38^{\prime} \mathrm{N}\right)$, March-April 1999, under bark, leg. A. Berokv (AMNH); Suriname: 1 male, Saramacca, West Suriname Rd., 108 km WSW

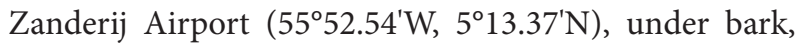
$30 \mathrm{~m}$ elev., 9.6.1999, leg. Z. Falin \#SUR1F99048 (KNHM); 1 male, same location, but $178 \mathrm{~km}$ WSW $\left(56^{\circ} 18.48^{\prime} \mathrm{W}\right.$, $4^{\circ} 596^{\prime} \mathrm{N}$ ), splintered tree trunk collected by pyrethrum fogging, 25 m elev., 13.6.1999, leg. Z. Falin \#SUR1F99070 (KNHM); Brazil: Amazonas, 1 male, Manaus, Rd. to Itacoatiara $\left(59^{\circ} 42^{\prime} \mathrm{W}, 2^{\circ} 42^{\prime} \mathrm{S}\right), 6.3 .1971$, leg. U. Irmler (UIC); 3 females, Manaus, Reserva Ducke (59 59'W, $2^{\circ} 55^{\prime}$ S), under bark, Nov. 1971, 15.8.1971, leg. U. Irmler (UIC); 1 female, same location, $26 \mathrm{~km}$ NE Manaus, leaf litter, February 1995, leg. M. G. V. Barbosa (BMNH); Santa Catarina, Nova Teutonia, 11.1938, leg. F. Plaumann (NHMS); Paraguay: 1 female, without further data, leg. C. Fiebrig (ZMHU); 1 female, Villa Rica, 18.9.1923, leg F. Schade (NHMW); 9 males, 11 females, Cazaapa, Hermosa, prop. Lopez family, San Rafael

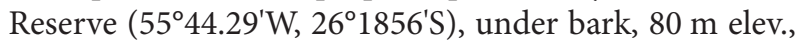
1.12.2000, 4.12.2000, leg. Z. Falin \#PAR1F00081 (KNHM, UIC); 1 male, 9 females, same location, but collected by pyrethrum fogging fungusy logs, 2.12.2000, leg. Z. Falin \#PAR1F00087 (KNHM); 3 females, same location, under bark, 4.12.2000, leg. Z. Falin \#PAR1F00105 (KNHM); 1 female, Itapua, Karonay, $17 \mathrm{~km}$ W San Rafael Reserve (5550.37'W, 26²45.53'S), 90-110 m elev., 19.11.2000, leg. F. Falin \#PAR1F00007 (KNHM).

Diagnosis: G. nitidum seems to be the sister species of G. cognatum SHARP, 1887 in South America. It closely resembles G. cognatum in size, absence of microsculpture and punctation. It can be differentiated from G. cognatum by the specific punctation of the pronotum. Whereas in G. cognatum the pronotal disc is punctate, in G. nitidum a central area is impunctate. Moreover, the aedeagi are distinctly different. In G. cognatum the apical lobe is straight with short apical curve pointing ventrad, whereas in $G$. nitidum the apical lobe is sinuate.

Description: Length: 1.9-2.1 mm. Colouration: light brown; elytra lighter reddish brown, legs light yellowish brown. 
Head: $0.31 \mathrm{~mm}$ long, $0.43 \mathrm{~mm}$ wide; eyes large; slightly prominent; 1.5 times as long as temples; temples narrowed to neck in convex curve; cheek-like; sides in front of eyes parallel up to base of antennae; then, abruptly narrowed in sinuate curve to anterior edge of clypeus; anterior edge of clypeus only one forth as wide as distance between base of antennae; setiferous punctures deep and coarse; on vertex between 6 and 7 punctures in irregular transverse rows; interstices between punctures half as wide as to as wide as diameter of punctures; setae as long as or longer as distance between punctures; between coarse setiferous punctures with extremely fine micro-punctation; without microsculpture; surface polished.

Antennae as long as head and pronotum combined; all antennomeres of equal width; second antennomere slightly wider than long, third twice as wide as long; fourth still slightly wider than twice as wide as long; penultimate antennomeres less than twice as wide as long; third to ninth antennomeres with long yellow setae; setae longer than width of antennomeres; antennomeres ten and eleven with short yellow setae.

Pronotum: $0.34 \mathrm{~mm}$ long, $0.37 \mathrm{~mm}$ wide; widest in anterior third; narrowed to anterior edge in short smooth curve; narrowed to posterior edge in long concave curve; setiferous punctures deep and coarse; on lateral parts, interstices less than half as wide as diameter of punctures; on disc, with group of four large setiferous punctures shaping quadrate, in anterior half two smaller setiferous punctures; between these groups of punctures with large impunctate space; at posterior angles with deep longitudinal groove; between coarse setiferous punctures with extremely fine micro-punctation; without microsculpture; surface polished.

Elytra: $0.56 \mathrm{~mm}$ long, $0.52 \mathrm{~mm}$ wide; sides slightly curved; widest in posterior third, but approximately parallel; shoulders well developed; slightly prominent; combined with anterior edge forming concave curve; discal carina indistinct; mainly marked by longitudinal rows of setiferous punctures; suture line consisting of dense line of small punctures continuing to posterior margin; in anterior half between suture and discal carina, six to seven setiferous punctures; in posterior half with longitudinal row of three to four setiferous punctures nearer to discal carina than to suture line; lateral side of discal carina marked by row of seven to eight elongate setiferous punctures; laterally another row of setiferous punctures separated from first row by impunctate space twice to three times as wide as diameter of punctures; without microsculpture; surface polished.

Abdomen on segments III to VII with transverse rows of deep and coarse setiferous punctures; punctures deeper and denser at base of segments; on anterior segments deeper and denser than on posterior segments; without microsculpture; surface polished.

Aedeagus smoothly curved; near apex sinuate; ending in acute apex; apical lobe laterally with longitudinal slightly curved line of sensillae from base to apical third; thin paramere reaching middle of apical lobe.
Glyptoma obscuricolle (BERNHAUER, 1908): 284

(Figs 14 A, B, C, 22B)

Calocerus obscuricolle BERNHAUER, 1908: 284

Type material examined: female, Holotype: Brazil, without further data of location or collecting (FMNH).

Further material examined: Brazil: 1 male, 3 females, Santa Catharina, Blumenau, 1889, leg. A. Hetschko (NHMW); 1 female only with location Santa Catarina (NHMW); 1 female, Santa Catarina, Theresopolis, leg. S. Fruhstorfer (ZMHU); Rio de Janeiro, Floresta de Tijuca, 3 males, 1 female, 17.7.1960, leg. H. Schubart (UIC); 1 male, same location, 17.3.1962, leg. I. Becker \& H. Schubart (UIC); 23 specimens, São Paulo, without further data, leg. J. Mráz (MNHP, AMNH, BMBH, UIC); 2 specimens, same location, June 1914, leg. J. Mráz (MNHP); 13 specimens, same location, July 1914, leg. J. Mráz (MNHP); 1 male, 1 female, same location without further data $(\mathrm{BMNH}) ; 1$ female with only information "Brazil" (BMNH); Paraguay: 1 female, Cazaapá, Hermosa, prop. Sosa family, San Rafael Reserve $\left(55^{\circ} 44.55^{\prime} \mathrm{W}\right.$, $26^{\circ} 19.15$ 'S), under bark, $90 \mathrm{~m}$ elevation, 4.12.2000, leg. Z. Falin \#PAR1F00105 (KNHM).

Diagnosis: G. obscuricolle (BERnHAUER, 1908) is the largest species of the group. The vertex of the head is finely punctate, whereas punctures are larger in the other species of the group. The longitudinal micro-striae of the vertex give a characteristic iridescent shine. The smoothly curved aedeagus resembles that of G. schuhi spec. nov., but the apical lobe is shorter and has fewer sensillae.

Description: Length: $3.2 \mathrm{~mm}$, Colouration: Black; elytra slightly lighter, dark brown; legs and antennae still lighter brown.

Head: $0.40 \mathrm{~mm}$ long, $0.60 \mathrm{~mm}$ wide; eyes slightly prominent; eyes as long as temples; temples smoothly rounded to the neck in convex curve; sides in front of eyes up to base of antennae parallel; parallel part as long as length of eyes; then, abruptly angulate; narrowed to anterior edge of clypeus in sinuate curve; anterior edge of clypeus 2.5 times as wide as distance between base of antennae; clypeus with moderately dense setiferous punctation; on average, interstices between punctures as wide as or wider than diameter of punctures; on vertex punctation sparer than on clypeus; interstices between punctures at least twice as wide as diameter of punctures; microsculpture extremely dense; consisting of diagonal micro-striae pointing to centre of vertex; on central line of vertex micro-striae more or less longitudinal; thus, surface matt, in central area slightly shiny.

Antennae as long as head, pronotum and half of elytra combined; antennomeres slightly widened anteriad; second antennomere slightly narrower than first; slightly wider than long; third to ninth antennomeres approxi- 
mately quadrate; tenth antennomere again slightly wider than long.

Pronotum: $0.50 \mathrm{~mm}$ long, $0.55 \mathrm{~mm}$ wide; widest in anterior third; slightly narrowed to anterior angles in smooth convex curve; anterior angles obtuse, but distinct; anterior edge also slightly convex; posteriad narrowed in concave curve to obtusely rounded posterior angels; posterior edge as wide as neck; setiferous punctation coarse and dense; central area less densely punctate; laterally, interstices between punctures restricted to extreme narrow ridges; punctures partly coriaceous; on disc, punctures smaller; interstices between punctures ranging between as wide as or even wider than diameter of punctures; pair of larger punctures in middle of posterior half in front of posterior edge; margined by transverse moon-shaped carinate structure separated by short longitudinal carinae; indistinct transverse depression in middle shortly behind anterior edge; longitudinal micro-striae microsculpture slightly weaker than on head; surface of large punctures with more or less isodiametric microsculpture; surface matt, but slightly shinier than on head.

Elytra: $0.80 \mathrm{~mm}$ long, $0.70 \mathrm{~mm}$ wide; widest in posterior third; sides slightly curved in convex curve, but nearly parallel; shoulders obtusely rounded; anterior edge margined; discal carinae distinct; slightly curved; lateral carina absent; suture line deeply impressed; marked by small extremely dense punctures; continuing to posterior edge; between suture line and discal carina two irregular rows of large slightly elongate setiferous punctures; punctation of outer row at discal carina denser than of inner row adjacent to sutural line; outer row partly coriaceous; laterad of discal carina another coriaceous row of setiferous punctures; laterally two more irregular rows of sparser punctures; interstices partly restricted to narrow ridges; longitudinally striate microsculpture dense; on surface of large punctures, microsculpture widely isodiametric; surface matt, but still shinier than on pronotum. Abdomen with irregular transverse rows of large punctures; on average, width of abdominal punctures as wide as width of punctures of inner rows of elytra.

Aedeagus smoothly curved from basal to apical lobe; apical lobe ending in acute apex; apical lobe laterally with two groups of sensillae; one with numerous sensillae at middle and one with four sensillae at base; paramere thin; reaching middle of apical lobe.

\section{Glyptoma schuhi spec. nov.}

(Figs 19 A, B, 23A)

Type material: male Holotype: Peru: Junin Prov., San Ramón de Pangoa, 40 km S Satipo, 750 m elev., 29.1.1974, leg. R. T. Schuh (AMNH). Paratypes: 1 male, 4 females with same data as holotype (AMNH, UIC); 3 males, 2 females, Junin Prov. between Cubantia \& Masaronquiari, 72 km SE Satipo, $950 \mathrm{~m}$ elev., 29.7.1972 (AMNH, UIC); Ecuador: 2 females, Pastaza Prov., Santa Clara env.,
Puyo, 950 m elev., 18.-21.7.2008, leg. W. Rossi \& I. Tapia (VAC, UIC).

Diagnosis: G. schuhi spec. nov. is similarly long as G. obscuricolle (BERNHAUER, 1908). It can be easily differentiated from G. obscuricolle (BERNHAUER, 1908) by the dense setiferous punctation of the elytral disc. In G. schuhi spec. nov. the space between suture and discal carina has at least partly three irregular rows of punctures, whereas in G. obscuricolle only two irregular rows are found.

Description: Length: 3.0-3.1 mm. Colouration: Black; elytra and antennae dark brown; legs light brown.

Head: $0.45 \mathrm{~mm}$ long, $0.60 \mathrm{~mm}$ wide; large eyes slightly prominent; longer than temples; temples narrowed to neck in smooth convex curve; sides in front of eyes parallel up to base of antennae; parallel part shorter than length of eyes; at base of antennae with obtuse nearly rectangular angle; narrowed to anterior edge of clypeus in sinuate curve; anterior edge of clypeus less wide than half of width between base of antennae; setiferous punctation moderately dense and deep; on average, interstices between punctures less wide than half of diameter of punctures; setae nearly twice as long as interstices between punctures; without microsculpture; surface polished.

Antenna distinctly longer than head and pronotum combined; all antennomeres nearly equally wide; second antennomere short; nearly twice as wide as long; tenth antennomere only one third wider than long; third to tenth antennomere with numerous long yellow setae; setae approximately as long as width of antennomeres.

Pronotum: $0.52 \mathrm{~mm}$ long, $0.55 \mathrm{~mm}$ wide; widest in anterior third; narrowed to anterior widely rounded angles in smooth convex curve; narrowed to posterior obtuse angles in concave curve; setiferous punctation deep and dense; width of punctures irregular; interstices between punctures restricted to small ridges; insertion of setae partly asymmetric; at posterior angles, punctation partly coriaceous; without micro $\neg$ sculpture; surface of ridges polished.

Elytra: $0.79 \mathrm{~mm}$ long, $0.78 \mathrm{~mm}$ wide; widest in posterior third, but nearly parallel; shoulders shortly rounded to emarginate anterior edge; discal carina irregular; partly broken; lateral carina absent; suture line marked by small coriaceous punctures; not continued to posterior margin; at posterior margin punctures larger; between suture line and discal carina two to three longitudinal rows of setiferous punctures; row of punctures adjacent to suture line and at inner margin of discal carina complete; intermediate row restricted to few irregular punctures; lateral row denser than inner row; laterally to discal carinae several rows of setiferous punctures; punctures of these rows larger than punctures of inner rows and partly coriaceous; interstices mostly restricted to small ridges; without microsculpture; ridges polished. 
Abdomen with dense and large setiferous punctation; interstices between punctures restricted to extremely small ridges; surface with deep and wide netlike microsculpture; microsculpture on posterior segments much weaker; anterior segments matt; posterior two segments shiny.

Aedeagus smoothly curved from basal to apical lobe; apex acute; apical lobe laterally with numerous sensillae; apical sensillae smaller than basal sensillae; paramere short; reaching basal fourth of apical lobe; slightly sinuate; basal half thick; in anterior half abruptly thinner.

Etymology: The species is named to honour the collector R. T. Schuh, who collected intensively in the Neotropical region.

\section{Key to the species}

1 Large species of 3.5 to $4.0 \mathrm{~mm}$, antennomeres longer than wide or quadrate

2 Head without any microsculpture, totally shiny G. laeviceps SHARP, 1887

Head at least partly at supraocular areas with microstriae, partly or totally matt or with iridescent shine

3 Head, pronotum and elytra with dense isodiametric microsculpture, totally matt G. opacum (SHARP, 1876) At least clypeus shiny and without microsculpture

4 Elytra with discal and at least weak lateral carina

5 Head with supraocular fine striate microsculpture, with iridescent shine G. rossi spec. nov.

Head except clypeus with dense isodiametric microsculpture and matt

6 Pronotum with large pseudo-punctures; setiferous punctures mostly on ridges between pseudo-punctures ........ 7 Pronotum with normal setiferous punctation, interstices between punctures wider

7 Elytra wider than long, pseudo-punctures of elytra combined to larger deep impressions

G. guadelupense (WENDELER, 1930)

Elytra quadrate or slightly longer than wide, pseudo-punctures of elytra isolated or combined to smaller grooves ... 8

8 Small species of $2.3 \mathrm{~mm}$ length, head without microsculpture, surface shiny, discal carinae of elytra distinctly convergent to scutellum G. hirticorne SHARP, 1887

- Larger species of at least $2.5 \mathrm{~mm}$ length, head with dense microsculpture and matt, discal carinae of elytra not distinctly convergent to scutellum, slightly curved

9 Elytra slightly longer than wide, pseudo-punctures of pronotum and elytra isolated

Elytra quadrate, pseudo-punctures of elytra at least partly combined to small grooves, pseudo-punctures of pronotum partly combined to irregular deep grooves

10 Head with weak microsculpture, surface shiny .....

G. crassicorne ERICHSON, 1840

Head with dense and deep microsculpture, surface matt G. lescheni spec. nov.

11 Temples convergent to neck, slightly convex, pseudo-punctures on pronotum less deep .... G. guianense spec. nov.

- Temples angulated, pseudo-punctures of pronotum partly combined to large deep grooves

G. amazonense spec. nov.

12 Small species of less than $1.9 \mathrm{~mm}$ length, elytra distinctly longer than wide, $\mathrm{L} / \mathrm{W}$ at least 1.2

Larger species of at least $1.9 \mathrm{~mm}$ length, elytra quadrate or only slightly longer than wide, $\mathrm{L} / \mathrm{W}$ not more than 1.1

13 Space between suture and discal carina with at least two irregular rows of punctures in posterior half ............. 14

Space between suture and discal carina with impunctate areas and only one row in posterior half

14 Large species of at least $3.0 \mathrm{~mm}$ length, space between suture and discal carina with dense punctation, partly with more than two parallel rows G. schuhi spec. nov. 
Smaller species of less than $3.0 \mathrm{~mm}$ length, space between suture and discal carina with two parallel irregular rows of punctures G. nitens (BERNHAUER, 1908)

15 Larger species of more than $3.0 \mathrm{~mm}$ length, vertex of head weakly punctate and with micro-striae, surface with slight iridescent shine G. obscuricolle (BERNHAUER, 1908)

Smaller species of 1.9-2.4 mm length, punctures on vertex of head larger 16

16 Elytra without microsculpture, shiny G. nitidum (BERNHAUER, 1908)

Elytra on impunctate space with fine longitudinally striate microsculpture, with iridescent shine or matt 17

17 Slightly larger species of $2.4 \mathrm{~mm}$ length, elytra slightly longer than wide, microsculpture denser and on impunctate space of elytra with iridescent shine G. denieri (Bernhauer, 1939)

Slightly smaller species of 2.1-2.2 mm length, elytra quadrate, microsculpture weaker and impunctate space of elytra shinier G. cognatum SHARP, 1887

\section{New combination}

\section{Espeson simplex (WENDELER, 1955) comb. $\mathrm{n}$.}

Calocerus simplex WENDELER, 1955: 191

Espeson simplex IRMLER, 2012: 346 new synonymy

Type material examined: 1 male syntype: Brazil: Santa Catarina, Nova Teutonia $\left(27^{\circ} 11^{\prime} \mathrm{S}, 52^{\circ} 23^{\prime} \mathrm{W}\right), 300-500 \mathrm{~m}$ elevation, leg F. Plaumann (ZMHU); 1 male, 1 female syntypes: with same date (MNPD).

According to notes published by Wendeler (1955), the types of Calocerus simplex (WENDELER, 1955) should be in his collection and in the collection of Franke. The collection of Wendeler was deposited in ZMHU, the collection of Franke was deposited in the collection of MNPD. A syntype of Calocerus simplex was not found in ZMHU, whereas two syntypes were found in MNPD. The finding of the syntypes of Calocerus simplex Wendeler in MNPD revealed that they were identical with Espeson simplex IrmLer, 2012. Irmler (2012) described the species on the base of specimens from the ZMHU, where it was deposited under the name Espeson simplex WENDELER. Reviewing the Espeson species and studying the material of ZMHU, IRMLER (2012) supposed that E. simplex was a manuscript name given by Wendeler for a new undescribed species. After finding the syntypes of Calocerus simplex in MNPD, it became clear that Wendeler (1955) described this species as Calocerus simplex. Later he found that the species belongs to the genus Espeson, but never published this transfer. So, syntypes of Espeson simplex labelled by Wendeler are deposited in ZMHU and two syntypes in MNPD. Thus, Espeson simplex IRMLER, 2012 is identical with Espeson simplex (WENDELER, 1955) and becomes its objective homonymic synonym.

\section{Discussion}

The species number of the genus Glyptoma ERICHSON, 1839 is relatively poor compared to other genera of
Osoriinae. Actually, only 18 species are known and few more species are expected. In the collections studied two species were represented only by females that might be new. The related genus Thoracophorus is represented with 35 species in the Neotropics and much more species are expected, e.g. recently described new species for Cuba (Irmler 2015). The status of the species G. punctatoplicatum Solsky, 1870 must remain open until the type is found in the Zoological Museum of S. Petersburg, Russia. The type specimen was collected in Cayenne, French Guiana. All other specimens labelled as G. punctatoplicatum originate from southern Brazil, which is too far away from the type locality to serve as reference for the species. They all were identified as G. nitens. A species occurring in French Guyana that matches the description of Solsky (1870) is G. cognatum Sharp, 1887. Thus it is most likely that G. cognatum is synonym to G. punctatoplicatum Solsky, 1870. Moreover, the specimens of Glyptoma seem to be rare and of low mobility. Only few specimens were found by flight intercept traps or other trap types. Most were collected directly by hand in their under bark habitat.

In spite of their low mobility, many species are found in a wide geographical range. The species G. nitidum and G. crassicorne represent widest distributions (Fig. 24). G. nitidum occurs in the whole tropical region of the South-American subcontinent from Paraguay to Trinidad, whereas G. crassicorne mainly occurs in Central America from Mexico to Panama, but also inhabits the northern parts of South America, from the Guayanas, via Venezuela to Ecuador. The distributions of closely related species reveal interesting patterns. G. cicatricosa MotsCHULSKy, 1857, G. rossii spec. nov., G. simile spec. nov. and G. opacum (SHARP, 1876) are certainly close relatives. G. cicatricosa lives in Central America and northern South-America, whereas G. opacum and G. rossii substitute it in the Andean region from southern Columbia to 
Bolivia. G. simile occurs in south-eastern Brazil and eastern South America overlapping with G. cicatricosa in the Guyanas, and with G. opacum in the lowland rainforest of the Amazon basin located between the distribution area of these three species.

The country of Brazil containing 8 species contributes with the highest number of species. The Guyanas are also relatively rich in species with: French Guyana 7 species, Guyana 5 species and Suriname 4 species. Species richness of all other countries ranges between 1 and 4 species. Thus, the Atlantic rainforest of south-eastern Brazil seems to be a hot-spot of biodiversity of the genus. Several species seem to be endemic in that region, e.g. G. obscuricolle and $G$. nitens. The genus is nearly absent from the West Indian archipelago. Actually, only Guadeloupe has one endemic species that, however, is known only by the type specimens which indicates that the species might be rare on the island.

\section{References}

Bernhauer, M. 1908: Beitrag zur Staphylinidenfauna von Südamerika. - Archiv für Naturgeschichte 74: 283-372.

Bernhauer, M. 1909: Zur Staphylinidenfauna von Südamerika. 6. Beitrag. - Bullettino Società Entomologica Italiana 40: 225-251.

Bernhauer, M. 1939: Zur Staphylinidenfauna Argentiniens und Brasiliens (Col.). (40. Beitrag zur südamerikanischen Fauna). - Revista de Entomologia 10: 231-249.

BLACKWELDER, R. 1943: Monograph of the West Indian beetles of the family Staphylinidae. - Smithsonian Institut, US National Museum Bulletin 182: pp 658.

BlackWElder, R. 1952: The generic names of the beetle family Staphylinidae. With an essay on genotypy. United States National Museum Bulletin 200: pp. 483.

ErICHSON, W. 1839/1840: Genera et species Staphylinorum Insectorum Coleopterorum Familiae. Morin, Berlin, pp. 1-954.

Fauvel, A. 1891: Voyage de M. E. Simon au Venezuela. Revue francaise d'Entomologie 10: 87-127.

Herman, L. 2001: Catalogue of the Staphylinidae (Insecta: Coleoptera). 1758 to the end of the second millennium. II. Oxyteline group. - Bulletin of the American Museum of Natural History 265: 1067-1806.

IRMLER, U. 2010: A new genus of Osoriinae in the Neotropical region with a cladistic analysis of the tribe Thoracophorini (Insecta: Staphylinidae: Osoriinae). Arthropod Systematics \& Phylogeny 68: 229-237.

IRMLER, U. 2015: Osoriinae of Cuba with description of new species and an identification key (Coleoptera: Staphylinidae: Osoriinae). - Acta Entomologica Musei Nationalis Pragae 55: 145-172.
LeConte, J. L. 1853. Revision of the Elateridae of the United States. - Transactions of the American Philosophical Society 10: 363-403.

Motschulsky, V. 1857: Énumeration des nouvelles espèces des coléoptères raportés de ses voyages par M. V. Motschulsky. - Bulletin de la Societe imperiale des naturalistes de Moscou 30: 490-517.

Scheerpeltz, O. 1970: Studien über die Arten der Gattung Calocerus Fauvel (Col. Staphylinidae, Subfam. Piestinae, Tribus Thorscophorini). (19. Beitrag zur Kenntnis der neotropischen Staphyliniden). - Mitteilungen der Münchener Entomologischen Gesellschaft 59: 130-142.

SCHENkLING, S. 1894: Nomenclator coleopterologicus. Eine etymologische Erklärung sämtlicher Gattungs- und Artnamen der Käfer des deutschen Faunengebietes. - Bechhold, Frankfurt/Main, pp. 224.

Sharp, D. 1876: Contributions to the Staphylinidae of the Amazon valley. - Transactions of the Entomological Society of London: 34-424.

Sharp, D. 1887: Biologia Centrali Americana: Insecta Coleoptera: 1-747.

Wasmann, E. 1890: Neue myrmekophile Staphyliniden aus Brasilien. - Deutsche Entomologische Zeitschrift 1890: 305-318. 

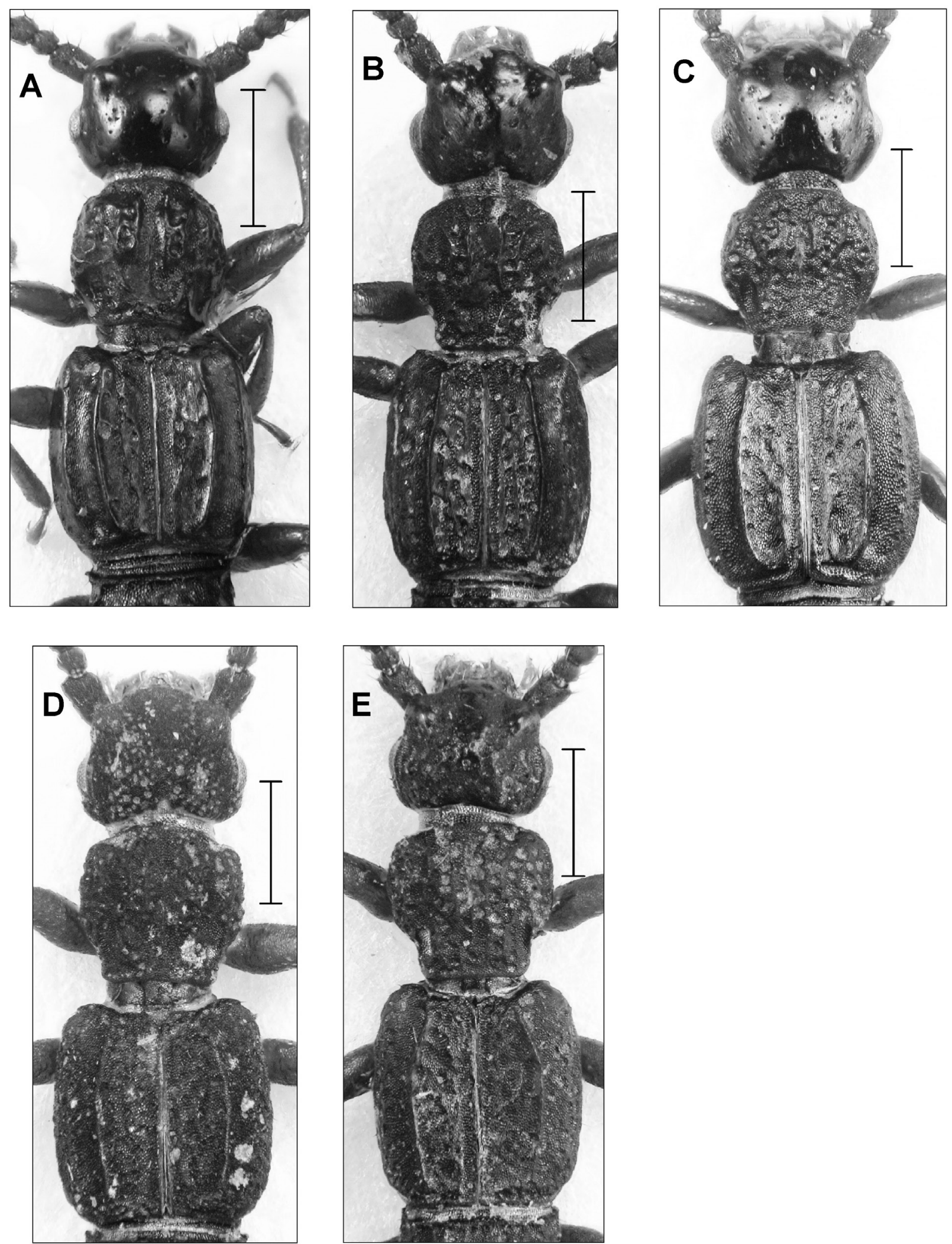

Figs 20: Fore body of Glyptoma laeviceps (A), G. cicatricosa (B), G. rossii (C), G. opacum (D), G. simile (E); scale bar 0.5 mm. 

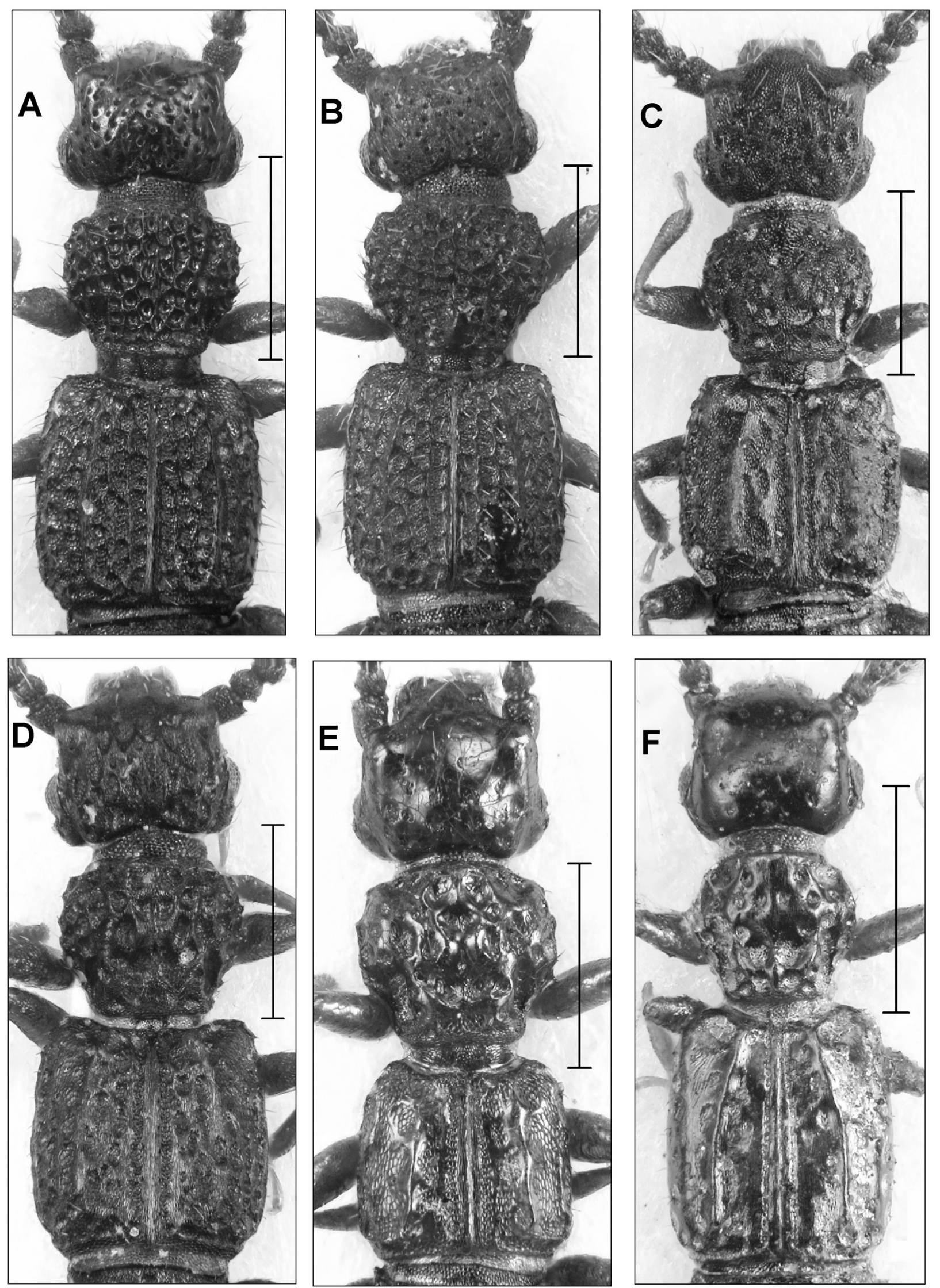

Figs 21: Fore body of Glyptoma crassicorne (A), G. lescheni (B), G. guianense (C), G. amazonense (D), G. guadelupense (E), G. hirticorne (F); scale bar $0.5 \mathrm{~mm}$. 

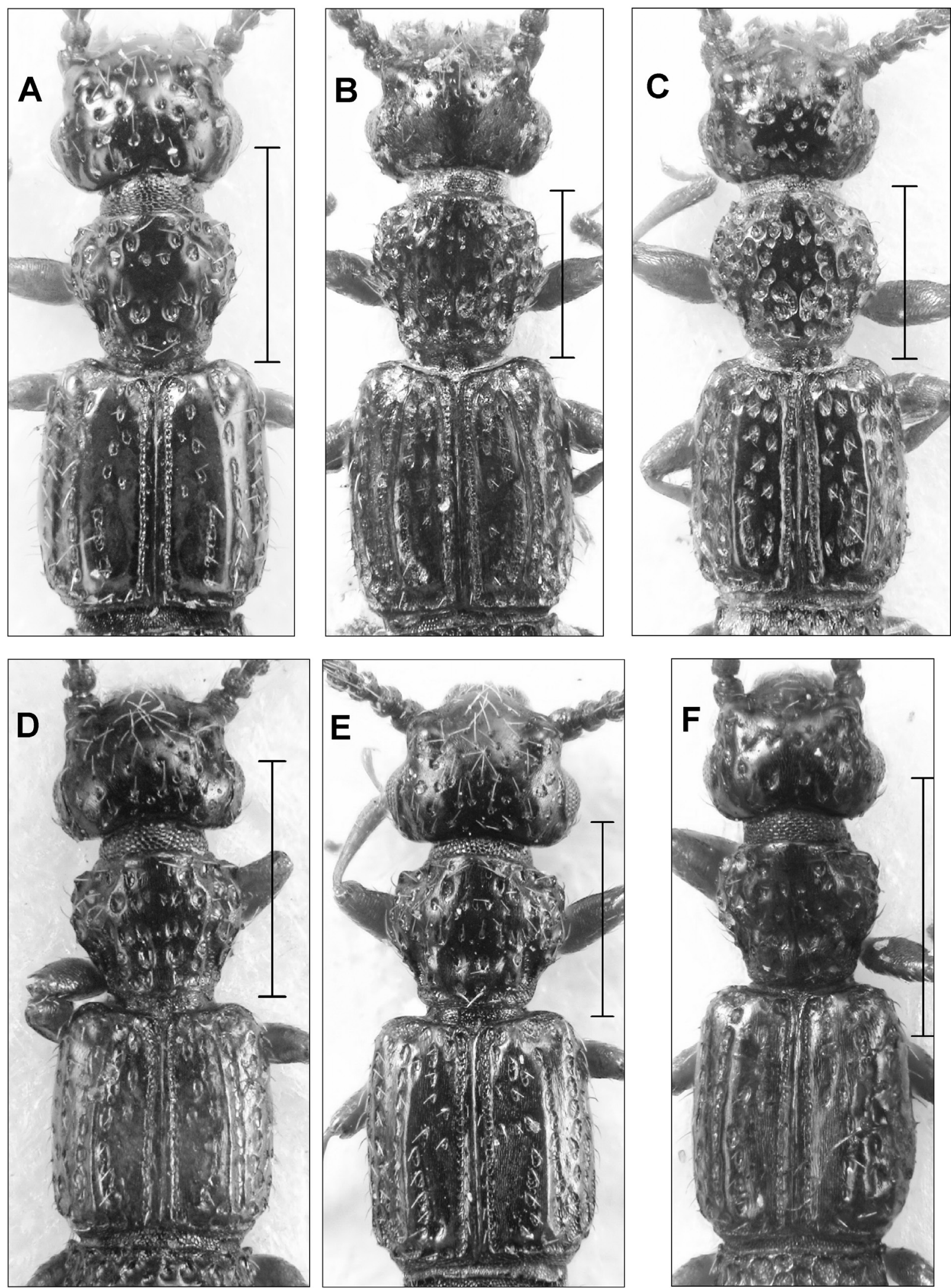

Figs 22: Fore body of Glyptoma nitidum (A), G. obscuricollis (B), G. nitens (C), G. cognatum (D), G. sanctaecatharinae (E), G. klimschi (F); scale bar $0.5 \mathrm{~mm}$. 


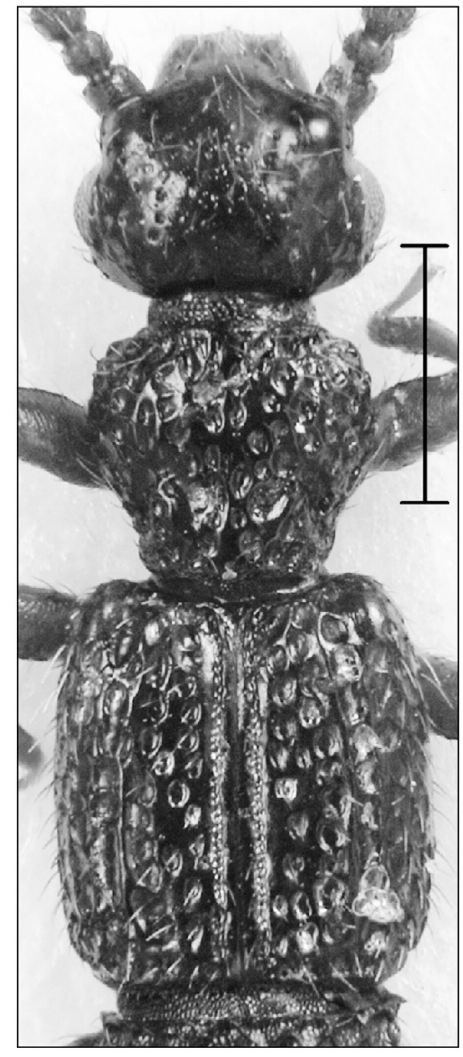

Figs 23: Fore body of Glyptoma schuhi (A); scale bar $0.5 \mathrm{~mm}$.
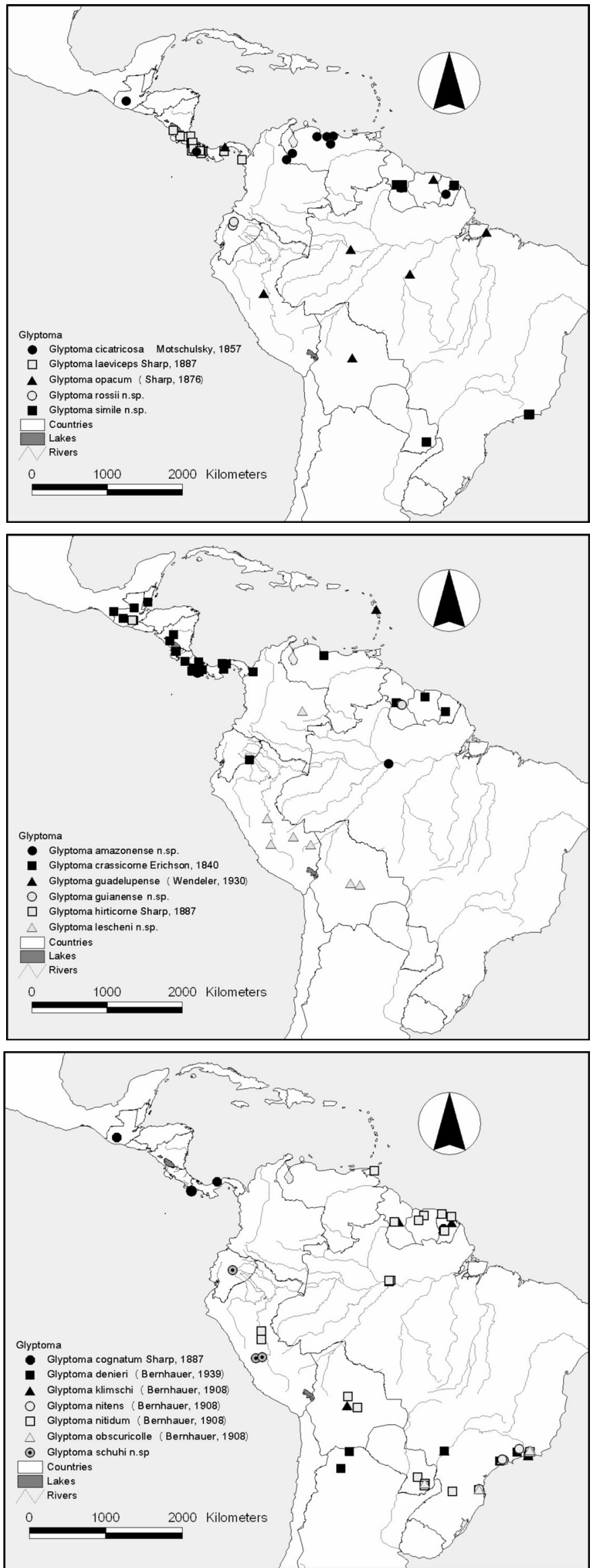

Map 1-3: Maps with the distributions for the three species groups differentiated. 